\title{
THE MYTH OF THE SOLE INVENTOR ${ }^{\dagger}$
}

\author{
Mark A. Lemley*
}

\begin{abstract}
The theory of patent law is based on the idea that a lone genius can solve problems that stump the experts, and that the lone genius will do so only if properly incented. But the canonical story of the lone genius inventor is largely a myth. Surveys of hundreds of significant new technologies show that almost all of them are invented simultaneously or nearly simultaneously by two or more teams working independently of each other. Invention appears in significant part to be a social, not an individual, phenomenon. The result is a real problem for classic theories of patent law. Our dominant theory of patent law doesn't seem to explain the way we actually implement that law.
\end{abstract}

() 2011 Mark A. Lemley. William H. Neukom Professor, Stanford Law School; partner, Durie Tangri LLP, San Francisco, CA. Thanks to David Rizk for extraordinary research assistance and Jeremy Bock, Rochelle Dreyfuss, Brett Frischmann, Jeanne Fromer, Rose Hagan, Ran Hirschl, Jon Howells, Ron Katznelson, Vic Kley, Amy Landers, Jeff Lefstin, Michael Martin, Rick McLeod, Peter Menell, Lisa Larrimore Oullette, Michael Risch, Ted Sichelman, Jay Thomas, John Turner, Hal Varian, and participants at workshops at Stanford Law School, the Hastings College of Law, and the IP Scholars' Conference for comments on a prior draft.

U of M Law School Publications Center, September 20, 2011, 1:42 PM 
Maybe the problem is not with our current patent law, but with our current patent theory. But the dominant alternative theories of patent law don't do much better. Prospect theory - under which we give patents early to one company so it can control research and development - makes little sense in a world in which ideas are in the air, likely to be happened upon by numerous inventors at about the same time. And commercialization theory, which hypothesizes that we grant patents in order to encourage not invention but product development, seems to founder on a related historical fact: most first inventors turn out to be lousy commercializers who end up delaying implementation of the invention by exercising their rights. If patent law in its current form can be saved, we need an alternative justification for granting patents even in circumstances of near-simultaneous invention. I offer another possibility: patent rights encourage patent races, and that might actually be a good thing. Patent racing cannot alone justify a patent system, but it may do more than any existing theory to explain how patents work in practice.

I. The Overwhelming Prevalence of Simultaneous Invention 7

A. Studies of Simultaneous Invention........ 7

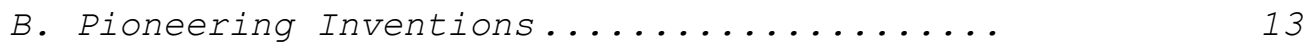

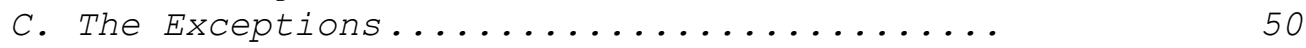

II. Theory Divorced From History ............. 55

A. Is Patent Law Encouraging New Inventions?. 55

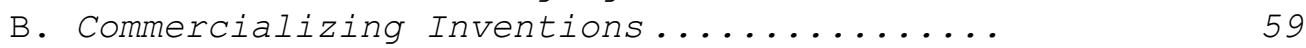

C. Disclosure Theory.................. 74

III. Patent Races: Toward an Alternative Theory of Patent Law 84

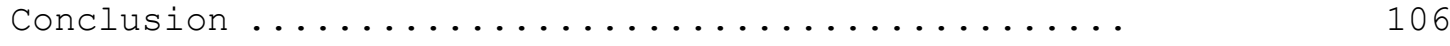


Any elementary-school student can recite a number of canonical American invention stories. Thomas Edison invented the light bulb from his famous home laboratory in Menlo Park, New Jersey. Alexander Graham Bell invented the telephone, again from his home invention laboratory, famously using the phone to call his assistant, saying "Come here, Watson, I need you." Orville and Wilbur Wright invented the airplane from their bicycle shop, taking it to Kitty Hawk, North Carolina to put it in the air. The list of lone genius inventors goes on and on: Samuel Morse and his telegraph, Eli Whitney and his cotton gin, Robert Fulton and his steamboat, Philo Farnsworth and the television, etc., etc.

Patent law is built around these canonical tales. First written in 1790, in the first year of Congress, the patent law betrays its individual-inventor bias at various points, from the requirement that patents always issue to individuals rather than companies to the traditional rule that the first to invent, not the first to file, is entitled to the patent. ${ }^{1}$ More importantly, the very theory of patent law is based on the idea that a lone genius can solve problems that

1. Chris Cotropia identifies the individual inventor motif as a driving force in the original patent system, albeit one that is mostly given lip service today. Christopher A. Cotropia, The Individual Inventor Motif in the Age of the Patent Troll, 12 Yale J.

L. \& Tech. 52 (2009).

The first-to-invent regime is on its way out as a result of the passage of the America Invents Act in 2011. But it remains the law for any patent application filed before March 16, 2013.

U of M Law School Publications Center, September 20, 2011, 1:42 PM 
stump the experts, and that the lone genius will do so only if properly incented by the lure of a patent. We deny patents on inventions that are "obvious" to ordinarily innovative scientists in the field. Our goal is to encourage extraordinary inventions-those that we wouldn't expect to get without the incentive of a patent. The canonical story of the lone genius inventor is largely a myth. Edison didn't invent the light bulb; he found a bamboo fiber that worked better as a filament in the light bulb developed by Sawyer and Man, who in turn built on lighting work done by others. Bell filed for his telephone patent on the very same day as an independent inventor, Elisha Gray; the case ultimately went to the U.S. Supreme Court, which filled an entire volume of U.S. Reports resolving the question of whether Bell could have a patent despite the fact that he hadn't actually gotten the invention to work at the time he filed. The Wright Brothers were the first to fly at Kitty Hawk as a result of an improvement they made to a basic wing structure designed by others, but their plane didn't work very well, and was quickly surpassed by aircraft built by Glenn Curtiss and others-planes that the Wrights delayed by over a decade with patent lawsuits. And on and on.

The point can be made more general: surveys of hundreds of significant new technologies show that almost all of them are invented simultaneously or nearly simultaneously by two or more teams working independently of each other. Invention appears in significant part to be a social, not an individual, phenomenon. Inventors build on the work of those who came before, and new ideas are often "in the air," or result from changes in market demand or the availability of new or cheaper starting materials. And in the few circumstances where that is 
not true-where inventions truly are "singletons"-it is often because of an accident or error in the experiment rather than a conscious effort to invent. ${ }^{2}$

The result is a real problem for classic theories of patent law. If we are supposed to be encouraging only inventions that others in the field couldn't have made, we should be paying a lot more attention than we currently do to simultaneous invention. We should be issuing very few patents-surely not the 200,000 per year we do today. ${ }^{3}$ And we should be denying patents on the vast majority of the most important inventions, since most of those seem to involve near-simultaneous invention. Put simply, our dominant theory of patent law doesn't seem to explain the way we actually implement that law.

Maybe the problem is not with our current patent law, but with our current patent theory. But the dominant alternative theories of patent law don't do much better. Prospect theory-under which we give patents early to one company so it can control research and development-makes little sense in a world in which ideas are in the air, likely to be happened upon by numerous inventors at about the same time. Commercialization theory, which hypothesizes that we grant patents in order to encourage not invention but product development, seems to founder on a related historical fact: most first inventors turn out to be lousy commercializers who end up delaying implementation of the invention by exercising their rights. And

\footnotetext{
2. Stephen Johnson, Where Good Ideas Come From (2010).

3. The U.S. PTO issued 219,614 patents in 2010. http://www.uspto.gov/web/offices/ac/ido/oeip/taf/us_stat.htm.
} 
disclosure theory, which justifies the grant of patents on the assumption that scientists read and learn from them, fails to grapple with the way learning occurs in the real world.

If patent law in its current form can be saved, we need an alternative justification for granting patents even in circumstances of near-simultaneous invention. In Part III, I offer another possibility. Patent rights encourage patent races. While patent races are usually derided as wasteful, there is reason to think that they might actually be a good thing. Invention might be motivated, or at least speeded, not merely by the hope of reward but by the fear of losing a race to a competitor that in turn obtains a dominant patent. This new "patent racing" theory turns the traditional incentive story on its head, ironically granting strong exclusive rights in order to promote competition, not monopoly.

There is support for the patent racing idea in the history of major inventions, but it is far from uniform. And patent racing theory does not fully justify patent law in its current form. As a result, I offer some suggestions for reforming patent law to take account of patent racing theory given the prevalence of simultaneous invention. But more research needs to be done before we are confident enough in the broad application of this theory to change patent law to conform to it. The result is, admittedly, somewhat unsatisfying. The evidence suggests that our primary theories of innovation don't support patent law in its current form, but there is not yet enough evidence to suggest a theory to replace it. This doesn't mean we should jettison the patent system; there is evidence that it has served the country 
well. But it may well mean we need to rethink the stories we tell ourselves about why we patent.

Part I discusses the remarkable prevalence of simultaneous invention throughout history. Part II discusses the problems this fact creates for each of the dominant theories of patent law. Part III discusses whether patent law can be salvaged, and if so, how.

\title{
I. The Overwhelming Prevalence of Simultaneous Invention
}

While patent law is based on the belief that important inventions are exceptional-that is, not obvious to most people in the field-the history of major inventions doesn't bear out that belief. The overwhelming majority of inventions, including the overwhelming majority of so-called "pioneering" inventions, are in fact developed by individuals or groups working independently at roughly the same time.

\author{
A. Studies of Simultaneous Invention \\ Multiple, independent studies ${ }^{4}$ show that what Merton calls \\ "singletons" are extraordinarily rare sorts of inventions. ${ }^{5}$ Indeed, \\ Lamb and Easton call multiple, simultaneous invention "the pattern of
}

\footnotetext{
4. Because how ironic would it be if one and only one academic had come up with the idea that ideas are rarely developed by one and only one person?

5. Robert $\mathrm{K}$, Merton, Singletons and Multiples in Scientific Discovery, 105 Proceedings of the Am. Phil. Soc'y 470 (1961).
} 
scientific progress." ${ }^{6}$ Merton's classic work suggests that inventions occur not merely because an individual did something particularly creative or surprising, but because the time and conditions were right. ${ }^{7}$ There are two components to this idea. First, invention is not a discontinuity, but an incremental step in an ongoing process. Inventors are working with the tools they are given and trying to improve those tools or use them to make something new. Schoenmakers and Duysters study 157 different inventions and conclude that they are largely based on extensions of existing knowledge. ${ }^{8}$

Second, invention by one and only one person or group is exceedingly rare. Far more common are different groups struggling with the same incremental problem, and achieving the same solution at roughly the same time. Ogburn and Thomas conducted the classic study here. They document 148 instances of simultaneous invention. Only rarely, they find, does an inventor come up with an idea that is not developed in similar form by others working independently. ${ }^{9}$

\section{D. Lamb \& S.M. Easton, Multiple Discovery: The Pattern of} Scientific Progress (1984).

7. Merton, supra note 5, at 473.

8. Wilfred Schoenmakers, Geert Duysters, The technological origins of radical inventions, 39 Research Policy 1051 (2010). 9. William F. Ogburn, \& Dorothy S. Thomas, Are inventions inevitable?, Political Science Quarterly, 83-98 (March 1922); William F. Ogburn, Social Change 90-122 (1922). For a more skeptical reading of the history, see Augustine Brannigan \& Richard A Wanner, Historical 
One might perhaps fault these studies for focusing on at least moderately well-known inventions. Perhaps many people aim at large targets, but smaller inventions have one and only one inventor. ${ }^{10}$ This would be a curious inversion of classical patent theories, which have always given more attention to protecting significant advances than to minor ones. In fact, however, what evidence there is suggests that simultaneous invention is a characteristic of smaller inventions as well. Empirical evidence suggests that between 90 and $98 \%$ of modern patent lawsuits are against independent inventors, not copiers. ${ }^{11} \mathrm{~A}$ significant fraction of patents are invalidated because someone else came up with the same idea before, often at roughly the same time. ${ }^{12}$ For inventions worth the trouble of patenting and enforcing in court, then - the very inventions the patent system might be thought to encourage - simultaneous invention seems to be the norm.

The author of the leading patent treatise of the nineteenth century, William Robinson, recognized this fact. He wrote:

Distributions of Multiple Discoveries and Theories of Scientific Change, 13 Soc. Stud. Sci. 417, 420 (1983).

10 Ted Sichelman suggested this possibility to me.

11. Christopher A. Cotropia \& Mark A. Lemley, Copying in Patent Law, 87 N.C. L. Rev. 1421 (2009).

12. See, e.g., John R. Allison \& Mark A. Lemley, Empirical Evidence on the Validity of Litigated Patents, 26 AIPLA Q.J. 185 (1998) . 
It is no answer. . . to say that the privileged inventor is generally the sole inventor, and that but for him the idea and its application would remain unknown. The contrary is true. With very few exceptions, every invention is the result of the inventive genius of the age, working under the demand of its immediate wants, rather than the product of the individual mind. ${ }^{13}$

Justice Frankfurter noted that "the history of thought records striking coincidental discoveries-showing that the new insight first declared to the world by a particular individual was 'in the air' and ripe for discovery and disclosure."14

There are various reasons for the prevalence of simultaneous invention. First, many inventions arise in response to consumer demand. If, suddenly, the world wants to participate in online social networks, many people will seek to fill that need, and-absent some large technical barrier-they will likely do so at roughly the same time. Second, inventions also arise in response to sudden changes in binding constraints on the supply side. If, for instance, batteries suddenly become dramatically cheaper and longer-lasting, a number of inventors may implement in portable devices ideas that previously could have been done only with stationary units plugged into a power

13. William Robinson, A Treatise Concerning the Law of Patents $\$ 29(1890)$.

14. Marconi Wireless Tel. Co. V. United States, 320 U.S. 1, 62 (1943) (Erankfurter, J., dissenting). 
outlet. The same phenomenon can work in reverse: a sudden shortage or spike in the price of one product can make the development of alternatives feasible for the first time.

Third, invention is often an incremental process, not a series of discrete ideas conceived in isolation. This fact is well-recognized in the literature. ${ }^{15}$ George Stigler has argued that each major idea in economics has been preceded by others that at least suggested it. ${ }^{16}$ The incremental nature of innovation means that inventions are more likely to occur simultaneously, because both inventors are building incrementally on the work that came before. An isolated flash of genius could strike at any time; the thirteenth step in a multi-stage inventive process is likely to come after the twelfth. But it also means that it is not the first flash of an idea that is necessarily

\footnotetext{
15. All inventors have the fortune of standing on the shoulders of the proverbial giants who preceded them. See Sony Corp. v. Universal City Studios, Inc., 464 U.S. 417, 477-78 \& n.28 (1984) (noting, in copyright case, that each person builds on the work of predecessors); Suzanne Scotchmer, Standing on the Shoulders of Giants: Cumulative Research and the Patent Law, 5 J. Econ. Persp. 29 (1991). As Justice Story explained well over a century ago, "in literature, science, and art, there can be few things, if any, that are strictly new and original throughout." Emerson v. Davies, 8 F. Cas. 615, 619 (C.C.D. Mass. 1845). Cf. James Boyle, Shamans, Software and Spleens (1996) (arguing that society systematically understates the extent to which creators borrow from preexisting works). 16. George J. Stigler, Economica (1955).
} 
the important one; the value of an idea often comes only after various people have honed and refined it in various ways. ${ }^{17}$ Many of the examples we will see involve a series of incremental steps; history has chosen to highlight the first person to make one significant step while ignoring the developments that precede and follow it.

Finally, the fact that inventions are based on certain immutable physical principles means that they will only work in certain ways. Inventors work not only within the constraints of physics and chemistry, but within the constraints of what we know about those physical principles. Donald Campbell compares simultaneous inventors to rats in a maze, each independently discovering the same path because it is the path that is there to be discovered. ${ }^{18}$ Joel Mokyr

17. $\quad$ Id.

18 Donald T. Campbell, Evolutionary Epistemology, Rationality, and the Society of Knowledge 71 (1987):

\begin{abstract}
A major empirical achievement of the sociology of science is the evidence of the ubiquity of simultaneous invention. If many scientists are trying variations on the same corpus of current scientific knowledge, and if their trials are being edited by the same stable external reality, then the selected variants are apt to be similar, the same discovery encountered independently by numerous workers. This process is no more mysterious than that all of a set of blind rats, each starting with quite different patterns of initial responses, learn the same maze pattern, under the maze's common editorship of the varied response repertoires. Their
\end{abstract}


has argued that simultaneity of inventions results from broad access to a shared base of knowledge about the world, and so has gone hand in hand with the acceleration of technological progress. When information about the world is scarce and closely guarded, only a few people are in a position to invent. Inventions are correspondingly rare, and so are simultaneous inventions. But as access to the base of human knowledge grows, so does the number of possible inventors and the likelihood of simultaneous invention. ${ }^{19}$

Prior empirical evidence, then, suggests that inventions rarely occur in isolation. They are socially-derived in significant respects. ${ }^{20}$ They build closely on what came before. And inventions are quite often made by multiple actors at about the same time.

\section{B. Pioneering Inventions}

"But wait," you may object at this point, "that evidence is talking about ordinary inventions. Surely the most important inventions-the truly pioneering ones-are the ones that other people couldn't have figured out."

In fact, however, the evidence does not simply show that most inventions result from simultaneous independent invention. It also

learning is actually their independent invention or discovery of

the same response pattern.

19. Joel Mokyr, The Gifts of Athena: Historical Origins of the Knowledge Economy 101 (2002).

20. For a discussion of the literature, see Amy L. Landers, Ordinary Creativity in Patent Law: The Artist Within the Scientist, 75 Mo. L. Rev. 1, 62-69 (2010). 
shows that the vast majority of the most important inventions of the past two centuries-the pioneering inventions that seem with the passage of history such radical departures from the prior art-were themselves the result of gradual social processes in which multiple inventors developed the key parts of the invention at about the same time. ${ }^{21}$

\footnotetext{
21. Defining a "pioneering" invention is difficult. For purposes of this paper, I don't need to work through those definitional difficulties. In general I treat an invention as a pioneer if it creates a new market, opens new opportunities in a variety of existing markets, or renders current technologies in an existing market obsolete. For discussions of the definitional issues, see, e.g., Mokyr, supra note 19; David C. Mowery \& Nathan Rosenberg, Paths of Innovation: technological change in 20th century America
} (1998) .

Courts have a well-established doctrine of "pioneering inventions," and so have considered these issues. Over a century ago the Supreme Court said that the "[m]ost conspicuous examples of such [pioneering] patents are the one to Howe, of the sewing machine; to Morse, of the electrical telegraph; and to Bell, of the telephone." Westinghouse v. Boyden Power Brake Co., 170 U.S. 537, 562 (1898). For a discussion of the legal doctrine of pioneer inventors, see, e.g., John R. Thomas, The Question Concerning Patent Law and Pioneer Inventions, 10 High Tech. L.J. 35, 37 (1995) ("Courts construe pioneer patent claims . . to encompass a broader range of so-called 'equivalents' during an infringement determination."); Samson Vermont, 
It is worth investigating these stories in detail, not only because they demonstrate that simultaneous invention and incremental improvement are the way innovation works, even for radical inventions, but because the lessons of history offer some valuable insights into how well existing patent theories jibe with the realities of innovation.

The steam engine. James Watt is famous to the world as the inventor of the steam engine. ${ }^{22}$ According to the common story, he patented his engine and used that broad patent on the basic concept to control the development of steam locomotion for decades, arguably delaying the development of that technology by others. ${ }^{23}$

In fact, however, Watt is not the first one to have come up with the idea of the steam engine. Indeed, one historian refers to a "general climate of interest in the steam-engine which seems to have been reaching fever pitch in the middle and later decades of the eighteenth century."24 Miller details the work of the many other

A New Way to Determine Obviousness: Applying the Pioneer Doctrine to 35 U.S.C. \$ $103(a), 29$ AIPLA Q.J. 375 (2001); Brian J. Love, Interring the Pioneer Invention Doctrine, _ N.C. L. Rev. _ (forthcoming 2011).

22. For general background on Watt, see Eric Robinson and A. E. Musson, James Watt and the steam revolution (NY: Augustus M. Kelley, 1969).

23 For discussion of this story, see Michele Boldrin \& David Levine, Against Intellectual Monopoly ch. 1 (2008).

24. David Phillip Miller, James Watt, chemist: understanding the origins of the steam age (London, UK: Pickering \& Chatto, 2009). 
inventors in the field; one very similar patent cited against Watt, in particular, leads Miller to conclude that it "helps to substantiate the suggestion that others were experimenting along similar lines to Watt, and independent of him."25

What Watt and his co-inventor Boulton in fact contributed was not the concept of the steam engine, but a particular implementation of that engine - the separate condenser, an improvement on the preexisting Newcomen steam engine. Interestingly, the subsequent development of steam engines was arguably driven by the Boulton-Watt patents, but not in the way we normally expect patents to work. Instead, the lock-up effected by Watt's broad patent rights drove subsequent inventors to seek different approaches to the steam engine, and it is one of those different approaches, designed to avoid the Watt patents, that actually succeeded in making steam engines practical. ${ }^{26}$

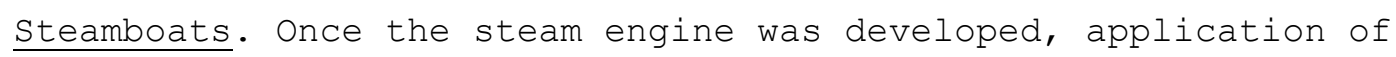
that engine to transportation of various forms became an obvious goal. To apply the steam engine to water travel, inventors needed to use the power generated by steam to push some form of oar through the water.

\footnotetext{
25. Id. at 6 .

26. See George Selgin \& John Turner, Strong Steam, Weak Patents, or, the Myth of Watt's Innovation-Blocking Monopoly, Exploded, _ J. I. \& Econ. __, draft at 2 (forthcoming 2011) ("Watt's monopoly rights may actually have hastened the development of the high-pressure steam engine, by causing would-be rivals to revive a supposedly obsolete technology so as to evade his patent.").
} 
The preferred solution to this problem was a rotating paddle wheel that the pressure of steam pushed through the water.

The steamboat is a classic example of independent invention. ${ }^{27}$ While Robert Fulton is acknowledged by the popular imagination as the inventor of the steamboat, in fact the historical evidence suggests that many different people developed steamboats at about the same time. ${ }^{28}$ Indeed, in the aftermath of the Revolutionary War, when the Articles of Confederation left patent rights to the states, different states issued patents to different claimants to the steamboat. ${ }^{29}$ The conflict between these inventors over patent rights issued by

\footnotetext{
27. See James Mak \& Gary M. Walton, Steamboats and the Great
} Productivity Surge in River Transportation, 32 J. Econ. Hist. 619, 625 $(1972)$

28. Jack L. Shagena, Who Really Invented the Steamboat?

Fulton's Clermont Coup 113-390 (2004) (eight different inventors, including Robert Fulton, but also William Henry, James Rumsey, John Fitch, Oliver Evans, Nathan Read, Samuel Morey, and John Stephens). 29 For discussion of these conflicts, see Frank D. Prager, The Steamboat Interference, 1787-1793, 40 J. Pat. Ofc. Soc'y 611, 613-15 (1958); Edward C. Walterscheid, Priority of Invention: How the United States Came to Have a "First-to-Invent" Patent System, 23 AIPLA Q.J. 263, 270 (1995); Michael F. Martin, The End of the First-to-Invent Rule: A Concise History of Its Origin, 49 IDEA 435, 451-53 (2009). 
different states was one of the driving forces of assigning patent rights to the federal government in the U.S. constitution. ${ }^{30}$

Fulton is remembered as the inventor of the steamboat primarily because he was successful in writing a broad patent to cover it, albeit one patented decades after other claimants. ${ }^{31}$

The cotton gin. Eli Whitney is the first famous U.S. inventor. On the common story, his cotton gin was a dramatic departure from old hand-driven cotton separating, was a quantum leap ahead of its competitors, and represented the first step in the mechanization of farming. ${ }^{32}$ Whitney patented his cotton gin, but had a hard time enforcing the patent against numerous copies that sprang up. ${ }^{33}$

30. See, e.g., Robert P. Merges et al., Intellectual Property in the New Technological Age 127 (5th ed. 2010) (identifying the conflict between the states over the inventor of the steamboat as a motivator for the Constitutional grant of patent power to the federal government).

31. William Woodward goes so far as to suggest that "Fulton might more properly be credited with the invention of the [patent] 'Claim' than of the steamboat." William Redin Woodward, Definiteness and Particularity in Patent Claims, 46 Mich. L. Rev. 755, 758 (1948). 32. The classic story is well recounted in Denison Olmstead, Memoir of Eli Whitney, Esq. (NY: Arno Press, 1972).

33. His frustration with patent litigation was so great that at one point he wrote to his friend Josiah Stebbins: "I have a set of the most Depraved villains to combat and I might almost as well go to hell 
The reality is a bit more complicated. Gins of some forms (mostly in roller form) have been around for thousands of years in Africa, the Middle East, India, and China; some of these were pedaled models, others hand-operated. ${ }^{34}$ The Indian, roller-type gin made it to the Americas and Caribbean by roughly 1750. Hand-cranked and hand-andfoot gins were in use in the Americas during this period; eventually, foot gins came to dominate the Americas pre-Whitney. Lakwete speculates they may have been developed indigenously, or alternatively could have come from China. ${ }^{35}$

Mechanical cotton gins were also well-known by Whitney's time. In 1788, Joseph Eve developed an inanimately powered, self-feeding roller gin that promised to diminish the number of accidents, which were a significant risk. By at least 1803, flywheels, which appear to have developed out of spinning technology, were adapted to the roller gin models. ${ }^{36}$

Whitney's idea was thus not the cotton gin, or even the mechanical cotton gin. Rather, his idea was to improve existing cotton gins by replacing rollers with coarse wire teeth that rotated through slits to pull the fiber from the seed. Lakwete suggests that this was really quite "unprecedented," and a demonstrable departure from the

in search of happiness as apply to a Georgia Court for Justice." http://inventors.about.com/cs/inventorsalphabet/a/eli_whitney_5.htm.

34. Angela Lakwete, Inventing the Cotton Gin: Machine and Myth in Antebellum America 1-20 (Baltimore, MD: John Hopkins UP, 2003).
35 . Id. at $27-31$.
36. Id. at $37-45$. 
basic roller model that had dominated all models for thousands of years. ${ }^{37}$ But even this may overstate Whitney's contribution, because other mechanics were using toothed gins before Whitney's invention, and had even patented toothed gins. Miller, in early correspondence with Whitney (May-June 1793), warned of two other anonymous inventors' advances and urged him to make progress. In January 1794, "a ginner manager hinted to Miller that Augusta mechanics were making toothed gins and that merchant ginners and planters were buying and using them." John Barcley filed a patent on a gin in 1795, which specified "setts or circles of teeth" (e.g., saws), suggesting, at least, that Whitney was not the only one to whom a toothed gin occurred. ${ }^{38}$ Whitney's gin worked well, and that's worth something. But it seems that other people were developing similar ideas at around the same time.

The telegraph. Samuel Morse is well-known as the inventor of the telegraph, the first realistic means of communicating information at a distance (and in many respects the Internet of its day). On the traditional story, Morse had an "aha" moment at a dinner with a geologist, Professor Jackson. Morse says: "We were conversing on the recent scientific discoveries in electro magnetism and the experiments in Ampere." Another guest asked Jackson whether an electrical signal fades over distance and Morse's dinner mate said no, that Benjamin Franklin had shown that it travels instantly across wire. This prompted Morse to think that "intelligence" might be "transmitted

37. Id. at $46-48$.

38. Id. at 58-61. 
instantaneously by electricity." ${ }^{39}$ Morse is perhaps most famous for "Morse code," the sets of long and short electrical signals that represented letters and numbers and enabled communication. Morse did in fact develop a working telegraph. But he was not the first to do so. There was significant interest in developing the telegraph in Europe, independent of Morse. ${ }^{40}$ The telegraph was independently developed at about the same time by a number of others, including Charles Wheatstone and Sir William Fothergill Cooke, Edward Davy, and Carl August von Steinhiel. ${ }^{41}$ Indeed, the Supreme Court observed that Morse, Steinheil, Wheatstone and Davy all invented "so nearly simultaneously, that neither inventor can justly be accused of having derived any aid from the discoveries of the other." 42

Morse's "idea" already existed in the world; the difficulty was in making it work over substantial distances. The key to Morse's new implementation was the development of efficient electromagnets that could sustain and boost electrical signals over wire. And it is Joseph Henry, not Morse, who made the original discovery of coiling wire to strengthen electromagnetic induction and even produced the first

39. Kenneth Silverman, Lightning Man: The Accursed Life of Samuel F.B. Morse 153-55 (NY: Alfred Knopf, 2003).

40. Id. at $151-52$.

41. O'Reilly v. Morse, 56 U.S. (15 How.) 62, 107, 110-11

(1854); Ken Beauchamp, History of Telegraphy 6-48 (2001).

42. O'Reilly V. Morse, 56 U.S. (15 How.) 62, 108 (1854). 
embodiment of the telegraph. ${ }^{43}$ Morse was aware of and explicitly built on Henry's work. ${ }^{44}$ Morse's patented contribution was in fact the application of Henry's powerful electromagnets to boost signal strength. And it is not even clear that he fully understood how that contribution worked; his patent refers to the use of the "galvanic" current without any recognition of the now-well-understood equivalence between electricity and magnetism. ${ }^{45}$

Others continued to improve on Morse's telegraph. Theodore Vail is credited with the telegraph key and with improving Morse code. ${ }^{46}$ His work also led to interest in communication of sound as well as data over electrical wires; more on that below. The sewing machine. Elias Howe, the inventor of the sewing machine, was recognized by the Supreme Court as one of the three most pioneering inventors of the $19^{\text {th }}$ Century. ${ }^{47}$ But Howe himself never built

43. See David Hochfelder, "Joseph Henry: Inventor of the Telegraph?" The Joseph Henry Papers Project (Smithsonian), available at http://siarchives.si.edu/history/jhp/joseph20.htm.

44. Id. at 159-60; Ken Beauchamp, History of Telegraphy 52 (London, UK: IEEE, 2001).

45. See Adam Mossoff, $\underline{O^{\prime} \text { Reilly v. Morse: Reevaluating a }}$ Foundational Patent Case in Historical Context (working paper 2010).

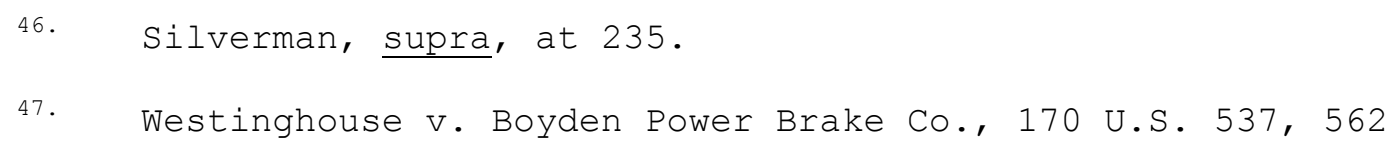

(1898) . 
a sewing machine. ${ }^{48}$ The first practical sewing machine was sold by I.M. Singer \& Co., and itself resulted from inventive work by Singer and a variety of others, including John Bachelder, Charles Morey, and Joseph P. Johnson, among many others. ${ }^{49}$ Howe sued Singer for patent infringement, and the resulting litigation continued for over a decade, concluding only when the parties agreed to form a patent pool, the Sewing Machine Combination. And it turns out the first inventor of the sewing machine may have been none of these individuals. Walter Hunt invented a sewing machine as early as 1834, ten years before Howe. ${ }^{50}$

The telephone. Alexander Graham Bell is, with Thomas Edison and the Wright Brothers, the most iconic American inventor. ${ }^{51}$ In part, this is because Bell's telephone not only worked, but grew to dominate the emerging telephone industry with a company bearing his name.

\footnotetext{
48. See, e.g., Adam Mossoff, The Rise and Fall of the First American Patent Thicket: The Sewing Machine War of the 1850s, Ariz . L. Rev. _ [draft at 37] (forthcoming 2011); Ryan L. Lampe \& Petra Moser, Do Patent Pools Encourage Innovation? Evidence From the 19thCentury Sewing Machine Industry (NBER working paper 2009), available at http://ideas.repec.org/p/nbr/nberwo/15061.html.

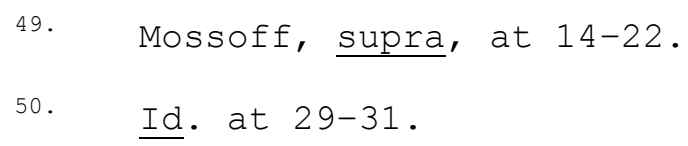


Bell described his invention as an "improvement in telegraphy." 52 The improvement consisted of allowing the electrical signals already transmitted over telegraph wires to be converted into sounds. But Bell was hardly the only one working on that problem. It was a well-known target to which many people applied themselves and made substantial progress; Bell built on that progress. Helmhotz developed a receiver apparatus that would convert signals to sounds. Helmhotz's invention was described to Bell by Alexander Ellis. Indeed, Bell testified that "[m]y knowledge of Helmhotz's apparatus for the artificial production of vowel sounds incited me to experiment of a similar character."53

A receiver needed to be coupled with a transmitter that converted sounds into electrical signals. Bell did in fact describe a transmitter in his patent. But it turns out he was not the first to do so. Philip Reis developed a transmitter in 1860, independent of Bell or Elisha Gray and apparently without their knowledge. ${ }^{54}$

\footnotetext{
52. U.S. Patent No. 174,465 (Mar. 7, 1876).

53. Michael E. Gorman, "Bell's Path to the Telephone" available at http://www2.iath.virginia.edu/albell/\#3; Michael Gorman, Transforming Nature 12 (Boston, MA: Kluwer Academic Press, 1998),

\$\$ 3.2.1-3.5, available at http://repont.tcc.virginia.edu/book/chap3/chapter3.html (quoting The Bell Telephone: The Deposition of Alexander Graham Bell in the Suit Brought by the United States to Annul the Bell Patents, (Boston: American Bell
} Telephone Co., 1908)).

54. See, e.g.,' The Telephone Cases, 126 U.S. 1, 66 (1888). 
Bell's real contribution to this preexisting technology seems to have been in the decision to vary the strength of the current to capture variations in voice and sound. But here too Bell did not work alone. Thomas Edison was working on the same problem, and also tinkered with variations in the strength of the current, though he ultimately took a different approach. ${ }^{55}$

Bell's ultimate invention put together a transmitter, a fluctuating current, and a receiver. But so did others. Elisha Gray filed an application in the patent office on the same day as Bell, following on other Gray applications that predated Bell's, ${ }^{56}$ and their inventions were ultimately put into interference. ${ }^{57}$ The resulting case went to the United States Supreme Court, and the Court's opinion takes up an entire volume of U.S. Reports. Despite the fact that Gray's

55. Paul Israel, Edison: A Life of Invention 131 (NY: Wiley, 2000); Robert V. Bruce, Bell: Alexander Graham Bell and the Conquest of Solitude (Ithaca, NY: Cornell UP, 1990). 56. See Bruce, supra note 48 , at $130-38$. 57. D.A. Hounshell, Bell and Gray: Contrasts in Style, Politics, Etiquette, 64 IEEE Proceedings 1305 (1976); D.A. Hounshell, Two Paths to the Telephone, 244 Scientific American 156 (January 1981).

In fact, Gray's filing was a "caveat" rather than a full patent application. A caveat was a mechanism by which an inventor working in a field could receive notice if anyone else filed a patent on the same technology, so that the parties could litigate the question of who was first. 
independent invention was different and in some ways better than Bell's, ${ }^{58}$ and despite the fact that Bell actually got his invention to work only in March 1876, well after his filing date, ${ }^{59}$ Bell won the case. The Court ruled for Bell despite the breadth of his patent claim, which covered any device "for transmitting vocal or other sounds . . by causing electrical undulations, similar in form to the vibrations of the air accompanying the said vocal or other sounds."60 And in dissent, Justice Bradley, writing for three of the seven Justices, called the claim of yet another inventor, Daniel Drawbaugh, for priority over Bell "overwhelming." 61

Bell invented a telephone, but he surely didn't do it from scratch, and he didn't invent the only one. Bell's iconic status owes as much to his victories in court and in the marketplace as at the lab bench .

The light bulb. If Alexander Graham Bell is known to the world as the inventor of the telephone, Thomas Alva Edison has equally iconic status as the inventor of the light bulb. Edison was a prolific

58. For instance, Gray's receiver worked better than the one Bell actually designed. Id.

59. Bruce, supra note 48, at 179-81. Compare U.S. Patent No. 174,565 (issued March 7, 1876).

60. The Telephone Cases, 126 U.S. 1, 531 (1888). For an excellent history of this litigation, see Christopher Beauchamp, Who Invented the Telephone? Lawyers, Patents, and the Judgments of History, _ Tech. \& Culture _ (forthcoming 2010).

61. Id. at $573-77$. 
inventor who branched out from his early work in telegraphy to a bewildering array of inventions, and he is rightly recognized as the first person to take invention from a hobby to a business. ${ }^{62}$ It seems clear, however, that Edison did not "invent" the light bulb in any meaningful sense. Electric lighting had a long history by the time Edison entered the field, starting with the arc lighting work of Sir Humphrey Davy. ${ }^{63}$ Even incandescent light bulbs-glass vacuum tubes through which a poor conductor of electricity was looped, giving off heat and light as an electric current was passed through it-were known before Edison entered the field. Sawyer and Man patented the incandescent light bulb; indeed, when Edison built his improved incandescent light bulb Sawyer and Man sued him for patent infringement. ${ }^{64}$ They weren't the only ones; Joseph Swan sued Edison in England for infringing Swan's incandescent light bulb patent and

\footnotetext{
62. Israel, supra note _, at 119; Andre Millard, Edison and the Business of Invention 1-41 (Baltimore, MD: John Hopkins UP, 1990); William S. Pretzer, Working at Inventing: Thomas A. Edison and the Menlo Park Experience (Baltimore, MD: John Hopkins UP, 2002).

63. For a discussion of the chronology of electric lighting up to the time of Edison, see Robert P. Merges \& John F. Duffy, Patent Law and Policy 269 (4th ed. 2007).

64. The Incandescent Lamp Patent, 159 U.S. 465 (1895). Sawyer and Man lost the suit because their patent claim was overbroad; while they had used a high-resistance filament made of carbonized paper to generate light, the court held their claim to all filaments of vegetable and fibrous material overbroad.
} 
prevailed, forcing Edison to merge his operations with Swan's. ${ }^{65}$ All in all, as the Supreme Court noted, "a large number of persons, in various countries" were working on incandescent lighting in the $1870 \mathrm{~s} \cdot{ }^{66}$

Edison's particular inventive contribution was the discovery of a new filament-a particular species of bamboo-that worked better than Sawyer and Man's carbonized paper because it had a higher resistance to electricity and so turned more of the power routed through the bulb into light. Higher resistance was a useful contribution, though it iw worth noting that Edison's core patent, no. 223,898, was filed in a rush to beat known competitors to market and included elements like a spiral filament that he himself soon abandoned.

Edison found commercial success with his bamboo filament, which lasted much longer than other carbonized vegetable material. But bamboo didn't turn out to be the future; subsequent inventors came up with still better filaments in short order, ${ }^{67}$ and modern incandescent

\footnotetext{
65. K.R. Swan, Sir Joseph Swan and the Invention of the Incandescent Electric Lamp 21-25 (1946 Longmans, Green and Co.). 66. Incandescent Lamp, 159 U.S. at _. 67. By 1903, Willis Whitnew had developed a metal-coated carbon filament that did not turn the inside of the lamp black. Georges Zissis \& S. Kitsinelis, State of the Art on the Science and Technology of Electrical Light Sources: From the Past to the Future, $42 \mathrm{~J}$. Applied Phys. 173001 (2009). Zissis and Kitsinelis also include a chronology of lighting-related inventions that predate Edison's. Id. at 3 .
} 
light bulbs operate on the high-resistance filament principle and use filaments that none of the inventors would have thought possible or feasible.

What Edison really did well was commercialize the invention. His light bulbs worked better than Sawyer and Man's, not only because he used a better filament but also because he was better at manufacturing them, creating a vacuum seal that significantly extended the life of a light bulb, making it a commercial success. And like Bell, he succeeded in the marketplace. There is no doubt that Edison added value. But his contribution to the development of the light bulb was an incremental one: one in a long chain of improvements.

The movie projector. While Edison is best known for the light bulb, he is also known to the world as the inventor of the movie projector. Edison did indeed make a movie projector of sorts, but not the kind we think of today as a movie projector. Edison took his electric light and shined it through a magnifying lens and a strip of cellulose nitrate film that had been developed by George Eastman for cameras. ${ }^{68}$ The resulting "Kinetoscope" ran a strip of film with successive images non-stop through the projection device. The audience could see motion, but it was all a blur. Francis Jenkins, later known as a key pioneer in television, built his own kinetoscope, but with an important difference: he modified it to project each image for a specified period of time (the current standard is 1/24 of a second), rather than to run the images continuously. The result was that the eye saw a series of static pictures that it interpreted as motion. It

68. Fisher \& Fisher, supra note _, at 40. 
is Jenkins's 1895 "Projecting Phantoscope," not Edison's earlier kinetoscope, that became the basis of the motion-picture industry. ${ }^{69}$ Why, then, don't we know Jenkins as the inventor of the movie projector? The answer is that his financial backer stole the prototype from his house and sold it to a theater chain, which marketed it as the "Edison Vitascope," Edison being a famous inventor by that time. Jenkins sued and eventually recovered some money from the theft, but the invention was known to the public ever after as Edison's. ${ }^{70}$ The automobile. Think of the invention of the automobile, and it is hard to avoid thinking of Henry Ford. His mass-production model turned automobiles from individual, hand-crafted devices into massmarket products that we still recognize even today, such as the Model $\mathrm{A}$ and the Model $\mathrm{T}$.

But Ford did not invent the automobile. Cars developed out of a combination of bicycles and tricycles, which involved wheels and a geared mechanism, and previous engines for propulsion such as steam engines and locomotives. The bicycle industry flourished briefly before the rise of cars, and the expertise gained in that industry informed auto manufacturing. For example, the Dodge brothers manufactured bikes before getting involved with Ransom Olds; ${ }^{71}$

\footnotetext{
69. Id. at $40-41$.

70. Id. at 41 .

71. David C. Mowery \& Nathan Rosenberg, Paths of Innovation:

Technological Change in 20th-Century America 50-52 (Cambridge, UK: Cambridge UP, 1998).
} 
similarly, Carl Benz adapted a tricycle design. ${ }^{72}$ Bicycles also helped build technologies such as pneumatic tires, and infrastructure such as the growth of well-paved roads also smoothed the transition to cars.

The original development of the auto was largely European. Carl Benz drove the first vehicle with an internal combustion engine in 1885, Gottlieb Daimler and Wilhelm Maybach built the first four-wheel car with a four-stroke engine, Niklaus otto developed the engine that Ford later claimed his design was based on, and other Europeans such as Peugot and Renault also developed early automobiles. ${ }^{73}$

Even in the United States, Ford was only one of many early automobile entrepreneurs. According to Raff and Trajtenberg there were over 150 car companies by the second decade of the $20^{\text {th }}$ Century. ${ }^{74}$ Buick founded his company in 1903. Ransom Olds began production in 1901. Henry Leland, a machinist, built engines for Ransom olds before Ford and formed Cadillac a year later. William Durant formed GM in 1908, eventually began acquiring others among the hundreds of car

72. Allen Nivens, Ford: the times, the man, the company 126-27 (NY: Scribner, 1954).

73. For discussion of these precursors, see Allan Nevins, Ford: The Times, The Man, The Company 91-118 (1954).

74. Daniel M.G. Raff \& Manuel Trajtenberg, Quality-Adjusted Prices for the American Automobile Industry: 1906-1940, NBER Working Papers 5035 (National Bureau of Economic Research, Inc. 1995); see also Nivens, supra note _, at 92-118. 
entrepreneurs. Ford was well aware of these figures through the scientific journals he read. ${ }^{75}$

The person who made the biggest effort to patent the automobile was none of these inventors. George Selden, a patent lawyer, was granted a broad patent on a combined gasoline engine with a carriage in 1895, having delayed his own patent for years in the PTO. Selden enforced that patent against others in the industry who used internal combustion engines, including Ford, until he ultimately lost on appeal in $1911 .{ }^{76}$ Notably, the appellate court ultimately rejected Selden's infringement claims because it found that prior art developed by still others, notably Brayton, predated it and precluded a broad construction of the patent. ${ }^{77}$

Nor was Ford the first American to successfully sell cars, and according to Bak and others he didn't particularly care-he saw the opportunity for improvement; his innovation was in the production process ("Fordism"), which really amounts to an incremental technological improvement in manufacturing, not in automotive technology. ${ }^{78}$ Ford successfully packaged the automobile, and helped to push us towards combustion away from steam or electric motive technologies. As a result, he is the person we most associate with the automobile. But he was not a pioneering inventor in the way patent law means the term. As Schmookler concludes, "[i]t seems almost obvious

\footnotetext{
75. Bak, supra, at 19-22.

76. See James J. Flink, The Automobile Age 51 (MIT Press 1990).

77 Columbia Motor Co. v. C.A. Duerr \& Co., 184 F. 893, 901 (2d Cir. 1911).

Richard Bak, Henry and Edsel: the creation of the Ford

Empire 21 (Hoboken, NJ: Wiley, 2003).
} 
- . that the automobile came when it did more because of economic and social changes than because of technological change as such."79 The airplane. Orville and Wilbur Wright, who ran a bicycle shop in Ohio, are known to the world as the inventors of the airplane. And they were indeed the first to fly a self-propelled heavier-than-air craft. But they did not operate in a vacuum.

Several aviation experts have argued that the development of the airplane is best characterized as a series of insights/inventions; it is unfair to suggest that there is a single inventor, these observers argue. ${ }^{80}$ Inventive interest in the idea of flying dates back at least to DaVinci. And by the time the Wright Brothers invented, George Cayley had conceived of and described the basic fixedwing/fuselage/tail-fins design that would become the basis of the airplane, and experimented with the design in gliders. ${ }^{81}$ Alphonse Penaud had designed a tail that promoted stability. ${ }^{82}$ Otto Liliental

79. J. Schmookler, Changes in Industry and in the state of Knowledge as Determinants of Industrial Invention, in The Rate and Direction of Inventive Activity 226-27 (Richard R. Nelson ed. 1962). 80. John Anderson, Jr., Inventing Flight: The Wright Brothers and Their Predecessors 16-19 (Baltimore, MD: John Hopkins UP, 2004); Tom D. Crouch, A Dream of Wings: Americans and the Airplane, 1875-1905 3 (NY: Norton, 1989).

81 Anderson, supra note _, at 37-39.

82. Id. at 92 . 
had flown a series of gliders. ${ }^{83}$ And Horatio Phillips developed widelyadopted airfoiled wings (the "airplane" that was to give the flying machine its name) ${ }^{84}$ By 1899, Anderson writes, all these aspects of an airplane were "accepted as the norm" even though no one had successfully flown one. ${ }^{85}$

The Wrights were aware of all this work. Indeed, they wrote to the Smithsonian in 1899 asking for all available information on the development of flight, and obtained at least the work just described. They also consulted with an experienced aeronautics engineer, Octave Chanute, who likely pushed them in productive directions. ${ }^{86}$ Orville himself said: "On reading the different works on the subject we were much impressed with the great number of people who had given thought to [mechanical flight], among some of the greatest minds the world has produced." 87

The Wrights invented only a particular improvement to flying machines, albeit a critical one: they came up with a way of warping a wing to control the direction of flight while turning a rear rudder to counterbalance the effect of bending the wing, maintaining the
83. Id. at 59-74.
84. Id. at 92 .
85. Id.
86. Id. at 94-95.
87. Anderson, supra note_, at 95. 
stability of the plane. ${ }^{88}$ The Wrights solved the stability problem by having a single cable warp the wing and turn the rudder at the same time. Their patent, however, was not so limited, and they successfully asserted it against subsequent inventors such as Glenn Curtiss. ${ }^{89}$ Curtiss improved the design of the wing by using ailerons, movable portions of the wing that had been developed by a consortium that included Alexander Graham Bell. A frustrated Curtiss was reported to have said that the Wright brothers believed their patent was so broad that anyone who jumped up and down and flapped their arms infringed it. ${ }^{90}$ The Wrights successfully enforced their patent to defeat all alternative aircraft, including many that surpassed the technical achievement of the Wrights. ${ }^{91}$ It was not until World War I that the patent suits were resolved, and it took the intervention of the U.S.

\footnotetext{
88. Id. at 101 ("With the exception of wing warping for lateral control (uniquely their development), [the Wrights] used existing technology.")

89. Wright Co. V. Paulhan, 177 F. 261 (C.C. S.D.N.Y. 1910) (L. Hand, J.) (holding the Wrights' patent to be pioneering and so entitled to broad scope).

90.

http://en.wikipedia.org/wiki/The_Wright_brothers_patent_war.

91. See U.S. Centennial of Flight Commission, Glenn Curtisss and the Wright Patent Battles, http://www.centennialofflight.gov/essay/Wright_Bros/Patent_Battles/WR1 2. htm.
} 
government to compel cross-licensing of various patents so that the various companies could build planes for the war effort. ${ }^{92}$

The Wrights, then, did make a critical step that others did not. But the step they took was one incremental step in a long series, and it was quickly surpassed by alternative technology developed by others.

Radio. Guglielmo Marconi is known to the world as the inventor of the radio. ${ }^{93}$ He thought of his invention as a wireless telegraph: that is, as an improvement in telegraphy that would allow the same sorts of data communication-the dots and dashes of Morse code-even between two points that were not connected with a telegraph wire. ${ }^{94}$ Marconi himself drew on prior work. Frost writes: "Marconi's first wireless telegraph-an invention that wrought radical changes on the

\footnotetext{
92. George Bittlingmeyer, Property Rights, Progress, and the Aircraft Patent Agreement, 31 J.L. \& Econ. 227 (1988); Peter C. Grindley \& David J. Teece, Managing Intellectual Capital: Licensing and Cross-Licensing in Semiconductors and Electronics, 39 Cal. Mgmt. Rev. 8, 34 n.4 (1997).

93. For general discussion, see Hugh G. J. Aitken, Continuous Wave: Technology and American Radio, 1900-1932 (Princeton, NJ: Princeton UP, 1985); W. Rupert Maclaurin, Inventions and Innovation in the Radio Industry (NY: The MacMillan Co., 1949).

94. Indeed, Ken Beauchamp's book History of Telegraphy divides consideration into "terrestrial telegraphy" and "aerial telegraphy" (aka radio) and devotes more time to the latter. Ken Beauchamp, History of Telegraphy (2001).
} 
world if one ever did-borrowed liberally from the decades-old practices of electrical engineering and overland telegraphy." 95 Indeed, Boldrin \& Levine document a number of other simultaneous, independent inventors who developed wireless telegraphy or were close to doing so between 1896 and 1898. ${ }^{96}$ Marconi's primary contribution to the work of others appears to have been the use of an elevated aerial-itself developed by Popov. Beauchamp describes Marconi as "in essence, a practical implementer of existing technology, rather than an innovator, much as Morse had been with terrestrial telegraphy." ${ }^{97}$ Interestingly, Marconi originally viewed his invention as a niche improvement in telegraphy, primarily of use in allowing ships at sea to communicate with each other. ${ }^{98}$ He did not see his invention as a medium for one-to-many communication, the primary use that was made of the technology for the next hundred years. That did not prevent him from claiming broad patents covering radio, however. The Marconi Company sued the United States for infringing its patents in 1916. The case lasted nearly thirty years and went to the Supreme Court, which

95. Gary Lewis Frost, Early FM Radio: Incremental Technology in Twentieth-Century America 23 (Baltimore, MD: John Hopkins UP, 2010) 96. Michele Boldrin \& David K. Levine, Against Intellectual Monopoly 215-18 (2006)

97. Beauchamp, supra note _, at 186 .

98. Nathan Rosenberg, The Future Was 'Obviously Not Obvious',

Stan. Observer, May-June 1994, at 13. 
held that Marconi's patents were invalid based on prior work by Nikola Tesla. ${ }^{99}$

Whoever was in fact the first inventor, making radio practical took a great deal of further work, both on the broadcast and on the receiving end. Radio receivers were developed independently by Edwin H. Armstrong and Lee de Forest, who engaged in a legendary patent interference over rights to the triode that was at the heart of the receiver and indeed of vacuum tubes used for decades thereafter. ${ }^{100}$ Johnson points out that de Forest misunderstood his own invention at every turn: "at almost every step of the way, de Forest was flat-out wrong about what he was inventing. The Audion was not so much an invention as it was the steady, persistent accumulation of error."101 Receivers were the subject of hundreds of overlapping patents in the first two decades of the twentieth century, and those patents led to debilitating litigation that immobilized the industry until the

\footnotetext{
99. Marconi Wireless Tel. Co. of Am. v. United States, 320 U.S. 1, 38 (1943). For a discussion of the history, see, e.g., Christopher A. Harkins, Tesla, Marconi, and the Great Radio Controversy: Awarding Patent Damages Without Chilling A Defendant's Incentive to Innovate,

73 Mo. L. Rev. 745, 751-59 (2008) (recounting the history) . 100. Radio Corp. of Am. V. Radio Eng'g Lasbs, 293 U.S., 1, 2-7 (1934). See George H. Douglas, The Early Days of Radio Broadcasting 12 (1987) .

101. Johnson, supra note _-' at 134.
} 
1920s, when the largest patent owners formed a patent pool to collectivize the rights. ${ }^{102}$

At the same time, radio broadcasting began to move from amplification modulation (AM) technologies, which convey information by modulating the amplitude of a carrier wave, to frequency modulation (FM) technologies that embed information in the frequency of the wave and permit more channels to share close proximity. The classic history views existing AM radio owners like RCA as resisting the move to FM, and the success of FM as attributable to one man, Edwin Armstrong. ${ }^{103}$ Gary Frost, however, "argues that FM emerged not so much from the mind of a single man but from a decades-long incremental and evolutionary process involving dozens of individuals."104 He identifies a number of others who developed FM technology before Armstrong. ${ }^{105}$ He also notes that most of the FM patenting during the developmental period was done by the large existing technology companies in radio. ${ }^{106}$ Indeed, Armstrong himself had a collaborative relationship with $\mathrm{RCA}{ }^{107}$

102. W. Rupert Maclaurin, Invention and Innovation in the Radio Industry (1949); Grindley \& Teece, supra at 10-12.

103. Lawrence Lessing, Edwin Howard Armstrong: Man of High Fidelity (1956).

104. Frost, supra note _, at 2 . 105. Id. at $23-53$.

106. Frost, supra note _, at 57 ("An examination of FM radiotelephone patent applications filed from 1913 through the 1930s indicates that the development of frequency-modulation radio occurred predominantly in three large corporations headquartered in the 


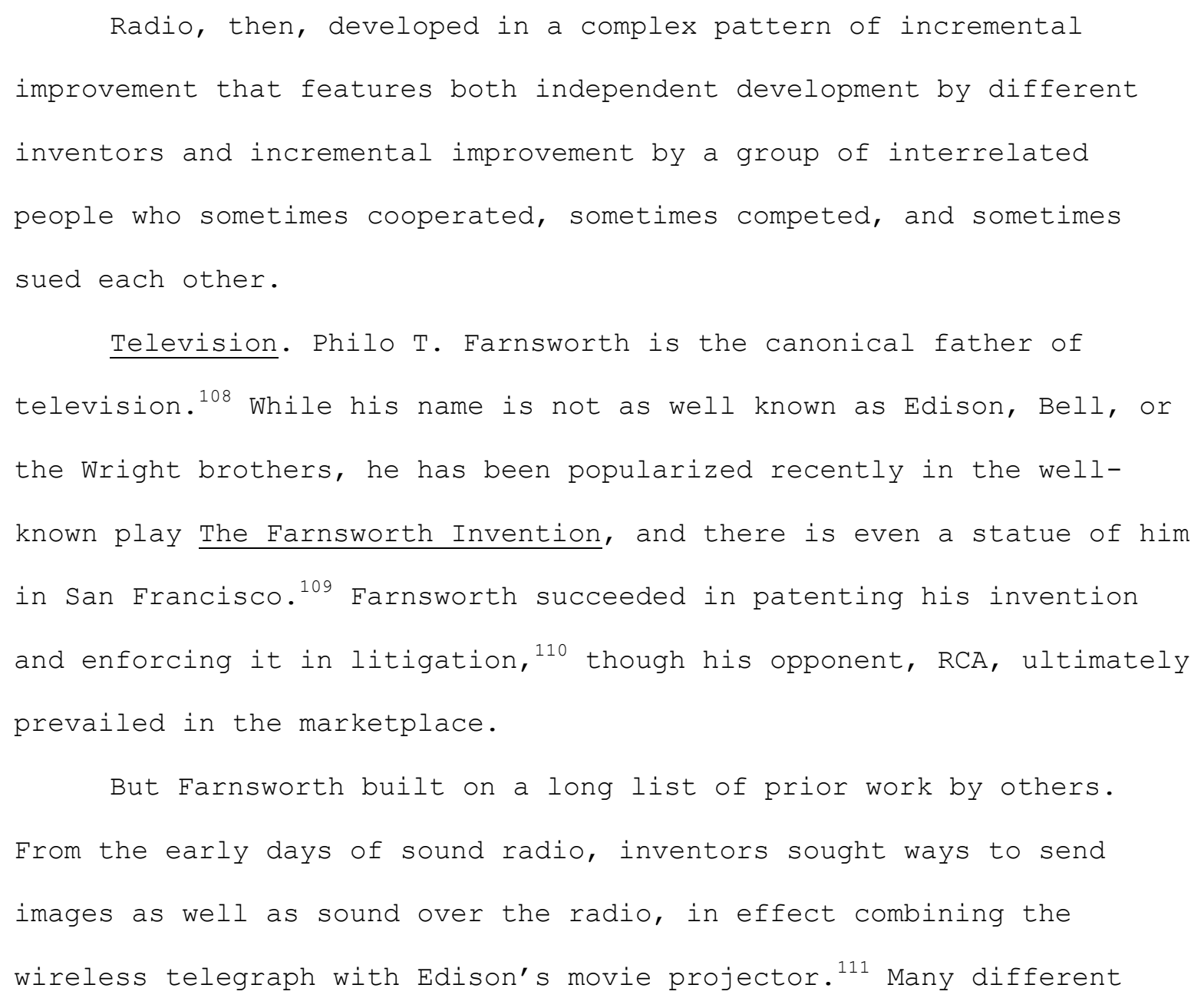


inventors tackled different aspects of the problem, including charles Francis Jenkins and Ernst Alexanderson, among others. ${ }^{112}$ As Webb puts it, "the development of television was simply too large an enterprise to have been the sole work of one gifted individual or even an inspired group. . . In the case of television, however, there was a lengthy preamble of independent and uncoordinated effort undertaken by a great many dedicated scientists and engineers working privately around the world."113

Indeed, these prior inventors actually made and implemented working televisions. As Fisher notes, "Jenkins was not the only one to take up the baton from Alexanderson. Once these two had shown that television was a real possibility, others began building transmitters and receivers, and during the first few months of 1928, radio stations in New York, Boston, and Chicago began televising, with thousands of people across the country buying or building receivers."114

What Farnsworth actually designed was a television receiver. But he wasn't the first to invent that either. As previously noted, receivers were already on the market in the 1920s. The receiver needed a means of projecting the image onto a screen. Vladimir Zworykin, working at Westinghouse, created the cathode ray tube, but company executives were underwhelmed and ordered him to work on other

112. Id. at $15-88$.

113. Richard C. Webb, Tele-visionaries: the people behind the invention of the television 5 (Piscataway, NJ: IEEE Press, 2005). 114. Fisher, supra note _, at 91 . 
things. ${ }^{115}$ Farnsworth did develop the "image dissector," the scanning mechanism that became the basis for the first functional, allelectronic television. ${ }^{116}$ But Farnsworth never made a commerciallyuseable image dissector. ${ }^{117}$

It may be accurate to describe Farnsworth as an inventor of the television, but surely not as the inventor.

The computer. There is substantial dispute as to who was the true first inventor of the computer. The Burks make a strong argument that it was John Atanasoff, a professor at Iowa State during World War II. ${ }^{118}$ The Burks argue that he had completed the computer during that time. ${ }^{119}$ Atanasoff himself says that it was ready for patenting and that he engaged a patent attorney to patent it, with the rights assigned to Iowa State. Nonetheless, it was never patented. He writes: During the spring and summer of 1942, I continued to work with [Iowa State] and Mr. Trexler to get the patent under way. There always seemed to be some reason why it should be put off, however, and put off it was. The patent 
was never applied [for] by Iowa State College, probably due to short-term financial considerations. ${ }^{120}$

What most people know to be the first computer, the Electronic Numerical Integrator and Computer (ENIAC), was developed by the Ballistics Research Laboratory in Maryland to assist in the preparation of firing tables for artillery. It was completed at the University of Pennsylvania's Moore School of Electrical Engineering in November 1945 and made public the following February. ${ }^{121}$ While it was long treated as the first computer and was in fact patented, the patent was held unenforceable on the ground that it was improperly derived from Atanasoff. ${ }^{122}$

But there are other claimants for the title of inventor of the computer. Many significant advances in computing came from the development of radar analysis and display systems by the U.S. and British militaries during the war. But the Germans were active in the same fields during the war. Indeed, the world's first programmable electric computer was invented by German civil engineer Konrad Zuse in 1941. The z3 Adder wasn't developed much further, and the only working copy was destroyed in an Allied bombing raid in 1944. But Zuse did

120. J.A.N. Lee, Computer Pioneers 37 (1995).

121 T.R. Kennedy, Jr., "Electronic Computer Flashes Answers". New York Times, Feb. 15, 1946.

122. Honeywell Inc. V. Sperry Rand Corp., 180 U.S.P.Q. (BNA) 673, 686, 747-50 (D. Minn. 1973). 
patent his invention, and IBM bought rights to those patents in $1946 .{ }^{123}$

Lasers. The laser was invented in 1957 in a physics laboratory at Columbia University that was working with "masers," which stimulated microwaves until they were emitted in a coherent beam. A team of professors at Columbia (Charles Townes and Arthur Schawlow) and a graduate student working with them (Gordon Gould) submitted separate patent applications for an "optical maser," or laser. ${ }^{124}$ The applications were put into interference, which was then appealed within the Patent office and eventually to the court of appeals. Townes and Schawlow were declared the first inventors in $1966 .{ }^{125}$ But Gould continued to pursue patents on his invention and obtained a fundamental patent in 1977. He enforced it in court, but didn't ultimately prevail until 1988, thirty-one years after the invention of the laser and nearly thirty years after it was put into practical use. ${ }^{126}$

This interference is not a true case of independent invention, because the claimants were all working together. Notably, however, they were not the only ones working on the problem. And none of the

\section{John Alderman, Core Memory: A Visual Survey of Vintage}

Computers 10 (2007).

124. For a detailed discussion, see Nick Taylor, Laser: The

Inventor, the Nobel Laureate, and the Thirty-Year Patent War (2000).

125. Gould V. Schawlow, 363 F.2d 908 (C.C.P.A. 1966).

126. Kenneth Chang, Gordon Gould, 85, Figure in Invention of the

Laser, N.Y. Times, Sept. 20, 2005, at A27. 
competing claimants were the first to actually produce a working laser; Theodore Maiman did that in $1960 .{ }^{127}$

Polymer chemistry. The development of polypropylene was a true enabling technology, opening up a variety of fields from fabrics to plastics. Who actually first developed polypropylene was a matter of considerable dispute. The resolution depended on whether the first crystalline form or the later development of an actual usable form counted as the first true invention. Multiple patent applicants claimed to be first, and the resolution of the interference did not occur until 1982, twenty-eight years after the 1954 invention of polypropylene. ${ }^{128}$

127. Nick Taylor, Laser: The Inventor, the Nobel Laureate, and the Thirty-Year Patent War 117 (2000).

128. The multi-party interference was declared by the BPAI on September 9, 1958. See Standard Oil Co. V. Montedison, S.P.A, 494 F. Supp. 370, 374 (D. Del. 1980). The BPAI issued its final Opinion on priority on November 29, 1971. See id. at 375. The patent was filed on June 8, 1955, and issued on February 6, 1973. See id. at 374 n.5; see also U.S. Patent No. 3,715,344 (filed June 8, 1955). The BPAI decision was appealed to the United States District Court for the District of Delaware, see Standard Oil Co., 494 F. Supp. at 370, and then to the Third Circuit, see Standard Oil Co. V. Montedison, S.P.A., 664 F.2d 356 (3d Cir. 1981). 
There are many other examples I could discuss. ${ }^{129}$ But the message should be clear. Even the inventions that seem the most significant

\section{For instance:}

- Gutenberg was not the first to invent printing, or a printing press. He did develop moveable type, but the same basic idea had been developed in Asia centuries before, and was the subject of independent work in the west by Johann Fust and Lauren Coster. Mort, supra note _, at 194-95, E.C. Arnold, Ink on Paper (1972); W. Chappell, A Short History of the Printed Word (1970) .

- The telescope was independently developed by six different inventors in 1608 and 1609. See, e.g., D. Lamb \& S.M. Easton, Multiple Discovery: The Pattern of Scientific Progress 145 (1984); Samson Vermont, Independent Invention as a Defense to Patent Infringement, 105 Mich. L. Rev. 475, 479 (2006).

- The first electrical battery was invented independently in 1745 and 1746 by Dean von Kleist and Cuneus of Leyden. Johnson, supra note _, at 34 .

- Two different scientists (Joseph Priestly and Carl Wilhelm Scheele) discovered oxygen independently of each other in the 1770s. Id.

- The corset, itself the subject of one of the best-known Supreme Court patent cases, Egbert v. Lipmann, 104 U.S. 333 (1881), was itself the result of independent invention by multiple parties and a web of patent litigation. Kara W. 
Swanson, Getting a Grip on the Corset: A Feminist Analysis of Patent Law, _ Yale J. L. \& Feminism__(forthcoming 2011).

- Charles Darwin and Alfred Russell Wallace developed the theory of evolution mostly independently of each other in the 1850s, though they had shared some background research on species. Wallace sent his manuscript to Darwin in 1858, which prompted Darwin to finish his own book On the Origin of Species the following year; the Linnean Society had both of them present their works together. http://evolution.berkeley.edu/evolibrary/article/history 14

- William Shockley's invention of the transistor at Bell Labs appears to have been anticipated by the work of Julius Edgar Lilienfeld. Michael Riordan and Lillian Hoddeson, Crystal Fire: The Birth of the Information Age 146 (NY: W. W. Norton \& Co., 1997). And Herbert Matare and Heinrich Welker invented a "transistron" in Germany during World War II, disclosing their invention in 1948 at about the same time Bell Labs did. See Paul Rako, Who invented something depends on your definition of "something", Elec. Design Strat. News, Feb. 17, 2011, available at http://www.edn.com/blog/Anablog/40527Who invented something depends on your definition of something .php.

- James Watson and Francis Crick published their work on the double-helix structure of DNA in 1953. J.D. Watson \& F.H.C. Crick, A Structure for Deoxyribose Nucleic Acid, 171 Nature 737 (1953). They were aware when they published the work that 
they were in a race with Linus Pauling, who had published a paper hypothesizing a triple rather than a double helix. Watson and Crick later said that they thought Pauling was only six weeks away from discovering his error when watson and Crick made their discovery. http://www.exploratorium.edu/origins/coldspring/ideas/printit. $\underline{h t m l}$

- Jack Kilby at TI and Robert Noyce at Fairchild invented the integrated circuit (an electrical circuit built into a single piece of silicon) independently within a few months of each other. Id. at 256-65. Noyce said the simultaneous invention was no accident, because the invention built on existing knowledge coupled with the availability of new materials. "There is no doubt in my mind that if the invention hadn't arisen at Fairchild, it would have arisen elsewhere in the very near future. It was an idea whose time had come." Id. at 265. The parties litigated for years over their rights to the integrated circuit before settling the dispute with a crosslicense.

http://www.bbc.co.uk/history/historic_figures/kilby_and_noyce. shtml.

- The implementation of Noyce and Kilby's integrated circuit on a computer chip was the subject of a long patent dispute between two competing independent inventors. Gary W. Boone first filed a patent application disclosing an integrated circuit on July 19, 1971. See U.S. Patent No. H1970 (filed 
departures from the prior art are in fact generally the products either of simultaneous independent invention or of incremental development from multiple sources or both.

July 19, 1971). Interference No. 102,598 was declared on March 27, 1991, and the Board of Patent Appeals and Interferences (BPAI) finally reconsidered its earlier decision of priority on May 10, 1996. See Hyatt v. Boone, 146 F.3d 1348, 1351 n.1 (Fed. Cir. 1998). An opinion in the last appeal of the BPAI's decision awarding priority to Boone was issued on August 26, 1998. See id.

- The jet engine was developed in Britain by Frank Whittle and in Germany by Hans von Ohain and Max Hahn at roughly the same time, using the same principles. Mokyr, supra note _, at 101 n.39.

- The human genome was sequenced by two different groups working in parallel, at the same time and with knowledge of each other. One was the publicly-financed Human Genome Project, and the other a private venture by Craig Venter at Celera. The two reached their conclusion and published their results within two months of each other. International Human Genome Sequencing Consortium, Initial sequencing and analysis of the human genome, 409 Nature 860 (2001). J.C. Venter, The sequence of the human genome, 291 Science 1304 (2001). 
a book. ${ }^{135}$ Charles Goodyear discovered vulcanized rubber when a batch of rubber was accidentally left on a stove; Goodyear had previously thought that heat was a problem for rubber, not the solution. ${ }^{136}$ Wilson Greatbatch developed the pacemaker when he accidentally grabbed the wrong resistor from a box when he was completing a circuit. ${ }^{137}$ Louis Daguerre invented film when, having failed to produce an image on an iodized silver plate, he put the plate away in a cabinet filled with chemicals and the fumes from a spilled jar of mercury produced an image on the plate. ${ }^{138}$ And so on. ${ }^{139}$

\footnotetext{
135. Henry Petroski, The Evolution of Useful Things 84-86

(2001); http://web.mit.edu/invent/iow/frysilver.html.

136. Harold Evans, They Made America 97 (2004). Goodyear rejected the notion that this was an accident, saying that "[l]ike the falling of an apple, it was suggestive of an important fact to one whose mind was previously prepared to draw an inference . . ." Id. Nonetheless, despite his years of experiments, Goodyear's success came not from one of those experiments but from chance.
}

137. Wilson Greatbatch, The Making of the Pacemaker: Celebrating a Lifesaving Invention_(2000); Johnson, supra note _, at 135-36; http://science.discovery.com/brink/top-ten/accidentalinventions/inventions-02.html.

138. Johnson, supra note_, at 134-35. Note, however, that despite the serendipity of Daguerre's invention, he shares credit for the invention of the photograph with independent inventor William Henry Fox Talbot, and both of them were in fact predated by other, camera-less means of reproduction. See, e.g., Randy Kennedy, An Image 


\begin{abstract}
And then there is the photocopier. Chester Carlson (a patent attorney) invented the electrostatic photocopier decades before anyone else developed a similar technology. ${ }^{140}$ Carlson himself was, of course, building on the shoulders of others, and other efforts at automated reproduction were underway at the time of his invention. He was "aware that silver halide photography and other light-inducing chemical phenomena were exhaustively being pursued in the research laboratories of major corporations."141 But Carlson turned away from that avenue and towards the use of electrostatic forces on glass to collect a toner. Even then, Carlson's first step was to conduct "an extensive literature search" relevant reports and patents; he discovered that over 150 years prior to his invention, many phenomena and devices had been explored in (usually) isolated experiments, often involving
\end{abstract}

Is a Mystery for Photo Detectives, N.Y. Times, April 17, 2008, at B1, B5.

139. For additional examples, including the microwave oven, dynamite, the phonograph, X-rays, Teflon, and Velco, see Dean Keith Simonton, Origins of Genius: Darwinian Perspectives on Creativity 35-

36 (1999); Paul Thagard \& David Croft, Scientific Discovery and

Technological Innovation: Ulcers, Dinosaur Extinction, and the

Programming Language Java, in Model-Based Reasoning in Scientific Discovery 126 (1999).

140. David Owen, Copies in Seconds_(NY: Simon \& Schuster, 2004). 141. J. Mort, The Anatomy of Xerography: Its Invention and

Evolution 49 (Jefferson, NC: MCFarland \& Co, 1989). 
electrostatic effects. ${ }^{142}$ Some of those old physics experiments set out the science behind the technology that became xerography. ${ }^{143}$

Mort argues that even the photocopier example shows the interrelatedness of invention:

from afar [] appear as self-contained and clearly definable entities that spontaneously emerged from the mind and hands of one person . . . Closer examination, however, reveals a much more complex situation. Inventions are commonly produced in a climate of intense invention with a number of individuals striving to achieve similar ends, so that any retrospective analysis has to contend with defining the actual invention. ${ }^{144}$

And Carlson himself said that "[t]hings don't come to mind readily all of a sudden, like pulling things out of the air. You have to get your inspiration from somewhere and usually you get it from reading something else."145 Mort accordingly concludes that Carlson's invention "fits the classic mold" of incremental improvement. ${ }^{146}$

142. Id. at 49-52. That work includes Villarsy's work on revealing electrostatically recorded images in $1780 \mathrm{~s}$, id. at 49, 60, and physicist Paul Selenyi's experiments with "electrography" in the 1920s-30s, which paralleled Carlson's work and which he credited as inspirational. Id. at 49-52.

143. Mort, supra note_, at 1-3.

144. Id. at 194-203.

145. Id. at 49 .

146. Id. at 196 . 
But on balance I don't think the photocopier can be counted as either a case of simultaneous invention or of incremental improvement. Carlson did go down a different path, and there is no evidence of simultaneous or near-simultaneous invention. Indeed, Mort notes that "had Carlson been totally influenced by the state of knowledge in 1938 he might have been inclined to drop the whole idea" of electrostatic glass, since the rest of the world seemed focused on the use of crystals. ${ }^{147}$

David Owen, in his history of the photocopier, underscores both this fact and its rarity:

Few big inventions truly have a single inventor; most technological revolutions are essentially collective efforts, arising in several minds and in several places at more or less the same time, generated as much by cultural pressures as by spontaneous individual insight. . . Carlson, in contrast, was genuinely alone. He always credited Selenyi with having inspired him, but Selenyi never saw the connections that Carlson did. . . Carlson alone thought of a way to make copies easily and quickly on plain paper; no one yet has come up with a better way of doing it. ${ }^{148}$

History, then, suggests that overwhelmingly, inventions-even socalled pioneering inventions-are actually incremental improvements,
147. Id. at 79 .
148. Owen, supra note_, at 89. 
often made at roughly the same time by multiple inventors. That doesn't mean the inventions I have catalogued here have no value; far from it. Edison, Wright, Bell, and the rest made useful contributions to society. But they did not invent things out of whole cloth.

The few cases that don't involve simultaneous work are mostly the result not of deliberate invention, but of accident. The photocopier seems the primary exception to this story, the only case in which a single inventor working alone develops a wholly new product that no one else achieves at roughly the same time.

\section{Theory Divorced From History}

\section{A. Is Patent Law Encouraging New Inventions?}

Patent law focuses on extraordinary inventions-things that could not be done by people having ordinary skill in the art. The rationale is straightforward: if scientists doing their regular work can develop a new invention, the law doesn't need to encourage that work with exclusivity, and granting one party control over those obvious inventions will interfere with the development and implementation of those ideas by others. By contrast, nonobvious inventions-those that require extraordinary skill or some insight beyond ordinary scientific endeavor-presumably won't be developed by multiple inventors, and may need or at least benefit from the incentive exclusivity provides. This basic rationale underlies the orthodox utilitarian theory of patent law. We grant patents, on this theory, to encourage inventions we wouldn't otherwise get. And we do so at substantial cost, both in terms of static inefficiency and in lost opportunities 
for future improvement. ${ }^{149}$ These costs fall into five categories. First, intellectual property rights distort markets away from the competitive norm, and therefore create static inefficiencies in the form of deadweight losses. Second, intellectual property rights interfere with the ability of other creators to work, and therefore create dynamic inefficiencies. Third, the prospect of intellectual property rights encourages rent-seeking behavior that is socially wasteful. Fourth, enforcement of intellectual property rights imposes administrative costs. Finally, overinvestment in research and development is itself distortionary. ${ }^{150}$

If we are patenting things we would have obtained without the cost of a patent, on this theory, we're wasting our money and probably harming rather than helping innovation downstream. Even some alternatives to the basic incentive story also proceed from this

\footnotetext{
149. For discussion of those costs, see, e.g., Mark A. Lemley, The Economics of Improvement in Intellectual Property Law, 75 Tex. L. Rev. 989 (1997); Mark A. Lemley, Property, Intellectual Property, and Free Riding, 83 Tex. L. Rev. 1031 (2005). 150. Lemley, Free Riding, supra note_, at 1058-59. For discussion of the economics of these costs, see, e.g., See, e.g., William Nordhaus, Invention, Growth and Welfare: A Theoretical Treatment of Technological Change (1969); F. M. Scherer, Industrial Market Structure and Economic Performance 450-51 (2d ed. 1980) (documenting patent holders pricing in excess of cost); Robert $P$. Merges \& Richard R. Nelson, On the Complex Economics of Patent Scope, 90 Colum. L. Rev. 839 (1990).
} 
baseline assumption. John Duffy's "inducement theory," for example, takes this theoretical baseline seriously, suggesting that we ought protect only those things that would not have been created or disclosed absent a patent system. ${ }^{151}$

The overwhelming prevalence of both independent invention and incremental contribution calls this basic incentive story into serious question. Sam Vermont has argued that independent invention is evidence that patents over-reward invention in a particular industry, since either it was easier to do than we thought, so that we would have gotten the invention without the lure of the patent, or we encouraged too much entry in researching the idea, so that the patent incentive could have been reduced. ${ }^{152}$

The same is arguably true of incremental invention. If our "pioneering" inventors are in fact engaged in normal science, tinkering with the work of those who came before rather than inventing something wholly new, the traditional incentive case for patent protection is weakened dramatically. The work may be obvious, or perhaps not, under the patent 1 law, ${ }^{153}$ but it is in any event

\footnotetext{
151. Michael Abramowicz \& John F. Duffy, The Inducement Standard of Patentability, 120 Yale L.J. 1590 (2011);_John F. Duffy, A Timing Approach to Patentability, 12 Lewis \& Clark L. Rev. 343 (2008). 152. Samson Vermont, Independent Invention as a Defense to Patent Infringement, 105 Mich. L. Rev. 475 (2006).

153 While the inventions I described in Part I are not "obvious" to the layman, the fact that scientists working in the field achieved those inventions at about the same time is evidence that they are
} 
incremental rather than pioneering. Brian Love has accordingly called for the elimination of the pioneering patents doctrine. ${ }^{154}$ And if innovation is incremental, not discrete, a substantial literature suggests that we should limit patent rights substantially, because strong patent rights granted to one inventor in the chain will significantly restrain incremental innovation by later inventors. ${ }^{155}$ Finally, the presence of some patent rights (though not strong ones) may affect the market structure of industries. Jonathan Barnett has argued that industries with patent protection are more likely to disaggregate into manufacturing and inventing units; the presence of a patent right allows parties to achieve by contracting what they might otherwise have to achieve by vertical integration. ${ }^{156}$ Barnett sees this as support for the incentive story of patents, ${ }^{157}$ though it might more reasonably be thought of as a commercialization story. In fact, however, it is not clear that we need patents at all, and particularly

obvious in a legal sense. But there is room in the legal standard for inventions to be straightforward to a few people of extraordinary skill, so long as the ordinary scientist could not have achieved them. 154. Love, supra note _.

155. Merges \& Nelson, supra note_; Lemley, Economics of

Improvement, supra note _.

156. Jonathan M. Barnett, Intellectual Property as a Law of Organization, working paper (2010). See also, Dan L. Burk \& Brett McDonnell, The Goldilocks Hypothesis: Balancing Intellectual Property Rights at the Boundary of the Firm, 2007 U. Ill. L. Rev. 575. 157. Id. at 
strong patents, to achieve this effect; any sort of property right might provide the parties a basis on which to contract, even one that does not cover independent invention. ${ }^{158}$

Boldrin and Levine go so far as to call for the elimination of all patents. ${ }^{159}$ While I don't think such a radical step is warranted, it should be clear that the claim that we need strong patents to encourage discrete new inventions by those of extraordinary skill is largely belied by history. ${ }^{160}$ The patent system may encourage the occasional Chester Carlson to come up with something entirely new, but patent owners-even the owners of the most famous and important inventions-are overwhelmingly not people who have invented something no one else could have done. They are making incremental improvements alongside others tackling the same problem and often coming up with the same solution at about the same time.

\section{B. Commercializing Inventions}

The dominant alternative theory of patent law focuses not on incentives to invent, but on the development and commercialization of

\footnotetext{
158. See Mark A. Lemley, The Surprising Virtues of Treating

Trade Secrets as IP Rights, 61 Stan. L. Rev. 311 (2008) (arguing that

trade secrets serve the same purpose).

159. Boldrin \& Levine, supra note _.

160. A growing literature suggests that external incentives are not the primary driver of invention. See, e.g, Eric E. Johnson, Intellectual Property's Great Fallacy, http://papers.ssrn.com/sol3/papers.cfm?abstract_id=1746343; Fromer, supra note _ $;$.
} 
an invention once it has been made. ${ }^{161}$ I have previously referred to these theories as "ex post" rather than "ex ante" theories of IP, because they don't focus on people trying to invent but on what people do with an existing invention. ${ }^{162}$ There are two different strands of this commercialization literature. First, Ed Kitch has argued that we should grant broad patents over inventions in order to give the owner of that broad patent the incentive to further develop the field. ${ }^{163}$ This "prospect" theory analogizes patents to mining claims: give the patentee control over a certain area and it will have every incentive to maximize the value of that space. The future development Kitch seems concerned with is primarily improvement, though his argument certainly has implications for bringing an invention to market.

\footnotetext{
161. Joseph Schumpeter famously distinguished between inventionthe development of a new idea-and innovation-the implementation of that idea in practical form. Joseph A. Schumpeter, Capitalism, Socialism, and Democracy 84 (2d ed. 1947). For discussions of the distinction, see, e.g.,_Thomas M. Jorde \& David J. Teece, Innovation, Cooperation, and Antitrust, in Antitrust, Innovation and Competitiveness 47, 48-49 (1992); Richard R. Nelson \& Sidney G. Winter, An Evolutionary Theory of Economic Change 263 (1982); Oren Bar-Gill \& Gideon Parchomovsky, A Marketplace for Ideas?, 84 Tex. L. Rev. 395, 398 (2005). 162. Mark A. Lemley, Ex Ante Versus Ex Post Justifications for Intellectual Property, 71 U. Chi. L. Rev. 129 (2004). 163. Edmund Kitch, The Nature and Function of the Patent System, 20 J.L. \& Econ. 265 (1977).
} 
More recently a number of scholars have begun to argue for the protection of commercialization more directly. Michael Abramowicz argues that people won't have an incentive to be the first to bring a new product to market absent some form of market exclusivity. ${ }^{164}$ He and John Duffy have accordingly proposed keying patent protection not to inventive difficulty but to the need to invest in creating a new market. ${ }^{165}$ Ted Sichelman applies the Abramowicz-Duffy framework to argue for "commercialization patents" that give exclusive rights to the first to bring an invention to market; Sichelman would require that the invention being commercialized be both new and nonobvious, though it's not entirely clear why; his theory would seem to apply equally well to any product not on the market, no matter how old or straightforward the invention was. ${ }^{166}$ Most radically, Ben Roin has proposed granting patents to old drugs in order to encourage pharmaceutical companies to test and sell those drugs. ${ }^{167}$ These authors

164. Michael Abramowicz, The Danger of Underdeveloped Patent

Prospects, 92 Cornell L. Rev. 1065 (2007). Accord F. Scott Kieff, Property Rights and Property Rules for Commercializing Inventions, 85

Minn. L. Rev. 697 (2001).

165. Michael Abramowicz \& John F. Duffy, Intellectual Property

for Market Experimentation, 83 N.Y.U. L. Rev. 337 (2008).

166. See, e.g., Ted Sichelman, Commercializing Patents, 62 Stan.

L. Rev. 341, 345 (2010); Ted Sichelman, Taking Commercialization

Seriously, Eur. Intell. Prop. Rev. __ (forthcoming 2011).

167. Benjamin N. Roin, Unpatentable Drugs and the Standards of

Patentability, 87 Tex. L. Rev. 503 (2009). The logic of Abramowicz and 
depart more fundamentally from traditional patent law principles. Their proposed exclusivity isn't focused on encouraging improvement inventions, but on the purported undercommercialization of any sort of new product faced with market competition, obvious or not.

For our purposes, the relevant question is this: does commercialization theory in either form offer a reason to grant broad patent rights to an inventor even though the patent wasn't necessary to induce the invention? I think the answer is no.

Both prospect and commercialization theories have a number of problems. Prospect theory has been extensively (and to my mind devastatingly) critiqued elsewhere as a matter of theory. ${ }^{168}$ Similarly, I have argued that the commercialization theory fundamentally misapprehends market dynamics-that, as Hayek observes, ${ }^{169}$ we don't normally need supracompetitive returns or the prospect of exclusivity just to encourage someone to take an existing invention to market. ${ }^{170}$ The primary problems stem from the assumption both theories make that we need central control of either improvement or marketing in order to

Duffy's proposal also leads in that direction, though they do not go that far.

168. Merges \& Nelson, supra note _; Lemley, Free Riding, supra note _; Lemley, Economics of Improvement, supra note _. 169. F.A. Hayek, The Use of Knowledge in Society, 35 Am. Econ.

Rev. 519, 524 (1945).

170. Lemley, Ex Ante, supra note _. 
efficiently encourage the controller to invest in those activities. ${ }^{171}$ Ordinary economic rents, coupled with non-patent advantages such as first-mover benefits and brand reputation, have long proved sufficient to encourage entry into new markets even in the absence of patent protection. We don't have computer software or social networks because of patents; indeed, if anything patents interfere with market entry in those fields.

Nor is there good reason to believe that patents (at least as currently conceived) would be a particularly good solution to undercommercialization if we thought it did exist. Patents are generally not coextensive with market entry rights; they might cover one product that competes with another in a market, or (more likely) cover one small aspect of a product. Those patents can't meaningfully serve commercialization ends. ${ }^{172}$ And because patents today take an

\footnotetext{
171. The classic argument cited in favor of monopolists coordinating innovation is Schumpeter, supra note_, at 106 . For an application to patent law, see Edmund W. Kitch, The Nature and Function of the Patent System, 20 J.L. \& ECON. 265 (1977); F. Scott Kieff, Property Rights and Property Rules for Commercializing Inventions, 85 Minn. L. Rev. 697 (2001). Cf. Suzanne Scotchmer, Protecting Early Innovators: Should Second-Generation Products Be Patentable?, 27 RAND J. Econ. 322 (1996) (suggesting that incentives be weighted towards pioneers).

172. To be fair, Kitch and Sichelman may be arguing not for the existing patent system, but for some hypothetical different system that might serve their ends. But the fact that today's patent law
} 
average of four years after filing to issue, ${ }^{173}$ they are rarely supporting new commercialization; market entry in most fields today occurs well before the relevant patent rights are even granted, much less litigated.

Even if we thought there was a market failure to be solved in undercommercialization, and that patents might be well-positioned to solve it, there is good reason to fear that the costs of granting commercialization patents far exceed the benefits. ${ }^{174}$ There are a number of structural reasons monopolists are actually poor managers of an invention. They have less incentive to come up with disruptive new technologies that improve on the initial invention, because most of

doesn't serve that end means that they can't point to it to explain the commercialization we have seen without the broader patents they envision

173. In the late $1990 \mathrm{~s}$ the average delay was 2.77 years, John R. Allison \& Mark A. Lemley, Who's Patenting What? An Empirical

Exploration of Patent Prosecution, 53 Vand. L. Rev. 2099 (2000). And it has increased significantly since then. Ron Katznelson, The Perfect Storm of Patent Reform,

http: //works.bepress.com/rkatznelson/doctype.html.

174. As Michael Burstein observes, commercialization theories often focus on the putative benefits of patents for commercialization, but "generally do not take account of the dynamic social costs that accompany intellectual property." Burstein, supra note _ , at _. 
the sales they would be displacing are their own. ${ }^{175}$ They may simply decide to make money from their existing invention rather than keep working to improve it. Watt took that approach with his steam engine. ${ }^{176}$ Edison acted the same way in the light-bulb market, resting on his patent and his 75\% market share rather than improving his technology ${ }^{177}$

Even if the owner of a commercialization patent has an interest in improving the invention, he may not be very good at it. Economists have suggested that large firms may simply be structurally less able to innovate than small start-ups; ${ }^{178}$ the very success of a firm with a

\footnotetext{
175. Kenneth J. Arrow, Economic Welfare and the Allocation of Resources for Invention, in THE RATE AND DIRECTION OF INVENTIVE ACTIVITY 609, 620 (Nat'l Bureau of Econ. Research ed., 1962), reprinted in 5 KENNETH J. ARROW, COLLECTED PAPERS OF KENNETH J . ARROW: PRODUCTION AND CAPITAL 104, 115 (1985); Morton I. Kamien \& Nancy L. Schwartz, Market Structure and Innovation 29-30 (1982). 176. F.M. Scherer, Invention and Innovation in the Watt-Boulton Steam-Engine Venture, 6 Tech. \& Culture 165, 174 (1965) (quoting Watt letter to Boulton: "it is now full time to cease attempting to invent new things, or to attempt anything which is attended with any risk of not succeeding. . Let us go on executing the things we understand.") .

177. Bright, supra note _, at 91-92, 122.

178. Richard R. Nelson \& Sidney G. Winter, An Evolutionary Theory of Economic Change 279 (1982) (large firm structure may be inimical to radical innovation).
} 
strong monopoly right may make it harder for that firm to keep up with market developments. And even a well-motivated and talented improver will not be best-situated to develop all possible improvements and commercial applications in-house. The existence of a strong controlling patent means that anyone who has a new idea for how to use or improve an invention must get permission from the central controller. And there are lots of reasons why efficient licensing may not occur. ${ }^{179}$ Even if it does, the requirement for coordination can lead to delay and can stifle later creativity. ${ }^{180}$ Rent-seeking is a

\footnotetext{
179. See Rebecca S. Eisenberg, Patents and the Progress of Science: Exclusive Rights and Experimental Use, 56 U. Chi. L. Rev. 1017, 1072-73 (1989) ("The risk that the parties will be unable to agree on terms for a license is greatest when subsequent researchers want to use prior inventions to make further progress in the same field in competition with the patent holder, especially if the research threatens to render the patented invention technologically obsolete."); Mark A. Lemley, The Economics of Improvement in Intellectual Property Law, 75 Tex. L. Rev. 989, 1048-72 (1997) (offering a variety of reasons why granting exclusive control to pioneers is inefficient); Robert Merges, Intellectual Property Rights and Bargaining Breakdown: The Case of Blocking Patents, 62 Tenn. L.
} Rev. 75 (1994); Robert P. Merges \& Richard R. Nelson, On the Complex Economics of Patent Scope, 90 Colum. L. Rev. 839 (1990). 180. Robert P. Merges, Rent Control in the Patent District: Observations on the Grady-Alexander Thesis, 78 Va. L. Rev. 359, 381 (1992); Eric von Hippel, The Sources of Innovation 131-207 (1988). 
concern here, just as it was under the incentive-to-invent theory. Indeed, the risk may be much stronger, because on commercialization theory applicants are seeking a much broader patent right with which to coordinate subsequent economic activity. ${ }^{181}$ We can draw useful lessons about the value of central coordination in encouraging ex post behavior from the exceptional cases in which an inventor did come up with something new, and accordingly obtained substantial patent rights. Those lessons are not encouraging for granting broad exclusivity. First, singleton invention does not necessarily lead to quick commercialization. Quite the contrary: the few cases of substantial inventions made only by one inventive group generally involve quite a substantial delay between invention and commercialization. We waited more than two decades after Carlson's invention for a working photocopier, ${ }^{182}$ and it was not until after his core patents expired that we got plain-paper copiers. Alexander Fleming published his results in 1929, but it was more than a decade before anyone began to exploit that idea. ${ }^{183}$ For almost a decade, much of the medical world regarded the discovery of penicillin

\footnotetext{
181. Donald G. McFetridge \& Douglas A. Smith, Patents, Prospects, and Economic Surplus: A Comment, 23 J. L. \& Econ. 197, 198 (1980); John F. Duffy, The Marginal Cost Controversy in Intellectual Property, 71 U. Chi. L. Rev. 37, 53-54 (2004) (noting this problem). 182. Carlson invented xerography in 1930, but the Xerox 914 copier was not marketed until 1959. Mort, supra note _, at 199. 183. http://inventors.about.com/od/pstartinventions/a/ Penicillin.htm.
} 
as of little to no consequence. And when they did begin to imagine the therapeutic uses of the mold, it was not Fleming who led the way. It eventually fell to Florey's team at Oxford and to William Foley, Ernst Chain, Norman Heatley, and a small group of other researchers, to extract penicillin for therapeutic use and theorize its chemical structure; ${ }^{184}$ the use in medical treatment came still later. Edison's light bulb was somewhat better than the ones that came before it, but his patents were sufficiently broad that they shut down any further efforts to innovate by others until the core patent expired. ${ }^{185}$ Edison, meanwhile, having captured the market, stopped working on improving light bulb technology, turning his attention to other inventions. ${ }^{186}$ Relatedly, it is notable that initial inventors (whether singletons or multiples) frequently turn out to be pretty bad at commercializing their own inventions. Sometimes the problem is an understandable disconnect between the skills associated with invention and those associated with building a manufacturing business. But it is also quite common that inventors of important new technologies miss the importance of those technologies. Marconi thought the use of wireless radio technology would be to permit ships at sea to

\footnotetext{
184. Brown, supra note _, at 106-121; Macfarlane, supra note - at ix.

185. Arthur A. Bright, Jr., The Electric-Lamp Industry: Technological Change and Economic Development from 1800 to 1947 at 138-39 (1949); Lea Shaver, Illuminating Innovation, available at http://papers.ssrn.com/sol3/papers. cfm?abstract id=1658643. 186. Id. at 122 .
} 
communicate with each other; while that is in fact a use, it is hardly the most important one. ${ }^{187}$ Armstrong, the inventor of FM radio, thought he had invented a way of extending the reach of AM radio and broadening its bandwidth; he missed the things (like the absence of static) that actually made FM a success. ${ }^{188}$ Bell described his telephone as an "improvement in telegraphy," and Western Union turned down an opportunity to buy the patent for $\$ 100,000$, rejecting the telephone as "inherently of no value to us." 189 IBM didn't foresee the market for personal computers. ${ }^{190}$ The transistor was originally conceived primarily as useful in hearing aids. ${ }^{191}$ The steam engine was developed to pump water out of flooded mines. ${ }^{192}$ Railroads were originally envisioned as a way of getting goods to canals, which would be the dominant form of overland transportation. ${ }^{193}$ The VCR was initially marketed to TV stations as a means of airing reruns. ${ }^{194}$ And so on.

187. Nathan Rosenberg, The Future Was 'Obviously Not Obvious',

Stan. Observer, May-June 1994, at 13, available at

http://news.stanford.edu/pr/94/940601Arc4231.html.

188. Frost, supra note _, at 88-91.

189. Charlotte Gray, Reluctant Genius: Alexander Graham Bell and the Passion for Invention 129 (2006).

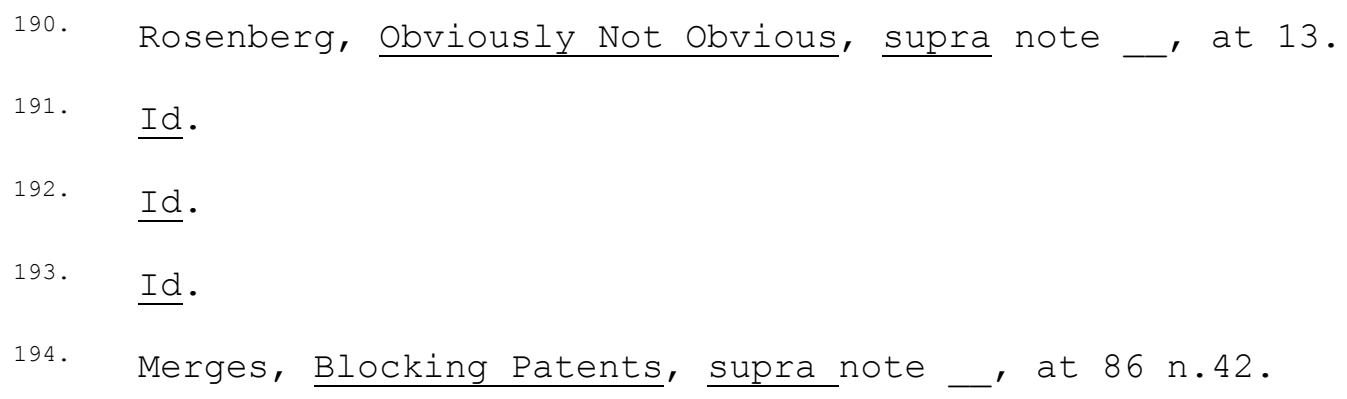


Further, inventors are often psychologically tied to their particular solution, even in the face of later evidence that other approaches work better. The Wright Brothers held up the development of airplanes for over a decade by enforcing their patents broadly against aileron wing structures while relying on their inferior wing-warping technology. ${ }^{195}$ AT\&T refused to adopt the packet-switching technology that became the basis for the Internet, delaying the deployment of that technology for decades. ${ }^{196}$

This latter commercialization problem is particularly significant for what I have called "enabling inventions": the sort of inventions that are likely to have a variety of different applications that open new markets or are scattered across existing ones. Inventors with one thing in mind-allowing ships to communicate with each other, 
say-are likely to focus on that use, paying less attention to other possible applications of their invention. The more control those inventors have over these pioneering technologies, the more difficult it may be for others to explore and implement these various new uses. ${ }^{197}$

The result of all these effects is that in industry after industry with broad pioneering patents, it is not until those broad patents expire or are otherwise avoided that substantial improvement can occur. Pioneering patents stifled the development of both airplanes and radio until the government stepped in and mandated that the patent owners share their technology. ${ }^{198}$ Steam engines improved dramatically only after the basic Watt-Boulton patents expired. ${ }^{199}$

\footnotetext{
197. The second strand of commercialization theory might avoid this problem by giving a different patent to each commercial implementation, but only in the more extreme form advocated by Benjamin Roin that divorces patents entirely from invention. 198. See Merges \& Nelson, supra note _, at 891-93 (noting Marconi's successful effort to hold up development of the triode until the U.S.Navy stepped in to mandate creation of a patent pool).

199. Boldrin \& Levine, supra note _, at 1-2. While more recent research has cast doubt on Boldrin and Levine's claim that the patents themselves directly suppressed improvements, that research suggests an alternative form of the same basic story: Watt and Boulton stuck with an inefficient technology, and improvements occurred only because others sought to design around that patented technology. Selgin \& Turner, supra note _.
} 
Sewing machines languished in patent litigation for over a decade until the parties resolved their dispute by forming the first patent pool. ${ }^{200}$

By contrast, industries in which the basic technologies were not patented, or in which patent rights were either narrow or unclear during the formative years of the industry, thrived in the absence of that strong central patent right. ${ }^{201}$

200. Mossoff, supra note _-.

201. The sum of all these stories is rather remarkable: for one reason or another, the basic building blocks of what might be called the enabling technologies of the twentieth century-the computer, software, the Internet, and biotechnologyall ended up in the public domain. Whether through a policy decision, a personal belief, shortsightedness, government regulation, or invalidation of the patent, no one ended up owning the core building blocks of these technologies during their formative years. This does not mean that there were no patents in these fields, or even that there were no major patents-far from it. But the patents that were obtained and enforced in these fields tended to cover implementations of or improvements to the basic building-block technologies. If patents were granted on the basic building blocks, it was often only after decades of litigation over inventorship.

The fact that previous enabling technologies were not generally patented may be thought a happy accident for 
There is one industry in which the commercialization story actually seems to work: pharmaceuticals. As Dan Burk and I have suggested, the regulatory structure of the modern pharmaceutical industry makes getting a new invention to market far more expensive and uncertain than actually developing that invention. ${ }^{202}$ The need for a special incentive to bring existing drugs to market is a function of the regulatory barriers to market entry, though, and not a general fact about innovation.

In short, the history of the most important inventions does not help to rehabilitate prospect or commercialization theory. Quite the contrary; the evidence suggests that strong patent control significantly impedes both commercialization and improvement of new

innovation-or at the very least for follow-on improvers who commercialized particular implementations of these technologies and then patented those implementations. Mark A. Lemley, Patenting Nanotechnology, 58 Stan. L. Rev. 601 (2005) . Steven Johnson argues that any new technology takes ten years to develop and another ten years to be accepted. Steven Johnson, Where Good Ideas Come From: The Natural History of Innovation 13-14 (2010). But that is a description of a few examples, and hardly an inevitable law of technological development.

202. See, e.g., Dan L. Burk \& Mark A. Lemley, The Patent Crisis and How the Courts Can Solve It 80-81 (2009). 
technologies. ${ }^{203}$ If we don't need patents to encourage new inventions, we certainly don't want to grant them in an effort to regulate the use made of those inventions in the marketplace.

\section{Disclosure Theory}

A traditional subsidiary justification for patent law is to encourage the disclosure of new inventions to the world. At one time, this theory was primary. For example, when the dissemination of information was hard, and inventions were simple, governments would grant patents to the first person to bring an invention into a country, even though they didn't invent it. ${ }^{204}$ More recently, the patent system has been described as a bargain with the public in which the inventor gives information about the invention in exchange for an exclusive right. ${ }^{205}$ The benefit the public gets from the bargain, on

\footnotetext{
203. For discussions of particular industries in which

competition appears to spur innovation, see, for example, Mark A. Lemley \& Lawrence Lessig, The End of End-to-End: Preserving the Architecture of the Internet in the Broadband Era, 48 UCLA I. Rev. 925, 960-62 (2001) (the internet); Arti Kaur Rai, Evolving Scientific Norms and Intellectual Property Rights: A Reply to Kieff, 95 Nw. U. I. Rev. 707, 709-10 (2001) (biotechnology); Howard A. Shelanski, Competition and Deployment of New Technology in US Telecommunications, 2000 U. Chi. Legal F. 85, 85 (telecommunications). 204. Merges \& Duffy, supra note _, at 4-5. 205. See, e.g., Eldred v. Ashcroft, 537 U.S. 186, 225 (2003) (referring to a patent as a "quid pro quo" for disclosure); Aronson v. Quick Point Pencil Co., 440 U.S. 257, 262 (1979). .(identifying
} 
this theory, is not (or not just) a new invention but the publication of new learning that might otherwise have been kept secret.

The historical evidence suggests that information disclosure and spillovers are important in the innovation process. ${ }^{206}$ Inventors learn from and build upon both their predecessors and their contemporaries. That learning quite often provides the inventor with the key insight that leads to the invention. Information flow, then, is something we very much want to encourage.

Disclosure theory cannot, however, support the modern patent system. Simply put, inventors don't learn their science from patents. The problem is in part one of law; the Federal Circuit has permitted a number of vague general disclosures that don't in fact communicate very much to anyone, and patent lawyers often have incentives to write those vague disclosures. ${ }^{207}$ So even those who read patents hoping to learn the state of the art would often be disappointed today. ${ }^{208}$

"promotes disclosure of inventions" as a key function of the patent system); Jeanne C. Fromer, Patent Disclosure, 94 Iowa L. Rev. 539, 542 (2009); Lisa Larrimore Ouellette, Do Patents Disclose Useful Information?, 25 Harv. J.L. \& Tech. (forthcoming 2012), available at http: //ssrn. com/abstract $=1762793$.

206. Brett M. Frischmann \& Mark A. Lemley, Spillovers, 107

Colum. L. Rev. 257 (2007).

207. See, e.g., Benjamin Roin, Note, The Disclosure Function of the Patent System (or Lack Thereof), 118 Harv. L. Rev. 2007, 2023

(2005); Alan Devlin, The Misunderstood Function of Disclosure in Patent Law, 23 Harv. J. L. \& Tech. 401, 403 (2010); Rebecca S. 
A second problem results from the structure of the modern patent system. The patent office is overwhelmed with work. ${ }^{209}$ Key patents that issued in a matter of a few months in the nineteenth century take years to issue today. ${ }^{210}$ And while a 1999 change in the law requiring

Eisenberg, Patents and the Progress of Science: Exclusive Rights and Experimental Use, 56 U. Chi. L. Rev. 1017, 1028 (1989). Even supporters of disclosure theory like Fromer acknowledge that "a good deal of evidence suggests that technologists do not find" patents "contain pertinent information for their research." Fromer supra note _' at 560. Brenner V. Manson, 383 U.S. 519, 534 (1966), noted the Court's concern with this problem nearly half a century ago; the majority and dissent disagreed over the import of arguments "that disclosure induced by allowing a patent is partly undercut by patentapplication drafting techniques." Id. (Harlan, J., dissenting) .

208. Ouellette, herself a believer in the value of disclosure, nonetheless reports that most scientists did not find a patent disclosure sufficient to allow one of skill in the art to reproduce the patented invention. Ouellette, supra note _ , at _.

209. Mark A. Lemley, Can the Patent Office Be Fixed?, in Rules for Growth 367 (Litan, Robert ed. 2011).

210. As noted above, the key telephone patents issued in a matter of months, sometimes as few as two months. See supra note _. By contrast, by the 1990s patent applications took 2.77 years to issue on average, John R. Allison \& Mark A. Lemley, Who's Patenting What: An Empirical Exploration of Patent Prosecution, 53 Vand. L. Rev. 2099 (2000). And pendency has increased substantially since that time. See, 
that most (though not all) patents be published eighteen months after publication is a step in the right direction, even inventors who read published patent applications are learning, not the state of the art today, but the state of the art two to three years earlier.

The final problem is more systemic. Because there are roughly 500,000 applications filed every year, ${ }^{211}$ and because our categorization systems are far from perfect, ${ }^{212}$ reading all the relevant patents in a field can be a Herculean task. And the fact that many of those patents obfuscate the technology at issue, deliberately or because we lack a clear language for communicating some types of inventions, means that the payoff from reading those applications is often dubious. Add to that the fact that lawyers often advise engineers not to read competitor patents for fear of becoming a willful infringer, ${ }^{213}$ and researching a new area of technology by

e.g., Ron Katznelson, The Perfect Storm of Patent Reform 5-6 (working paper 2008), available at http://works.bepress.com/cgi/viewcontent.cgi?article=1053\&context=rkat znelson.

211. See http://www.uspto.gov/web/offices/ac/ido/oeip/taf/ us stat.htm (more than 450,000 applications filed in each of 20072009).

212. On the problems with the PTO classification system, see Allison \& Lemley, Who's Patenting What, supra note _, at _. 213. See, e.g., Mark A. Lemley \& Ragesh K. Tangri, Ending Patent Law's Willfulness Game, 18 Berkeley Tech. L.J. 1085, 1100-02 (2003); Doug Lichtman, Substitutes for the Doctrine of Equivalents, 93 Geo. 
reading patents seems a doubtful idea at best. Far better for engineers to learn from article preprints, conferences, and conversations with colleagues. And indeed what evidence we have suggests that scientists in most fields turn to those sources for their scientific learning. If they read patents at all, it is to know what is owned, not what is known. ${ }^{214}$

Finally, for the disclosure theory to justify the patent system, it must be the case not only that the world actually reads patents and benefits from their disclosure, but that the incremental learning from the patents is sufficient to outweigh the costs to society of preventing anyone from using that learning to implement the technology

L.J. 2013, 2023 \& n.42 (2005). The problem of willful infringement has generally been thought to have diminished since In re Seagate Tech., LLC, 497 F.3d 1360 (Fed. Cir. 2007) (en banc), but a surprising number of cases still find willfulness. Christopher B. Seaman, Willful Patent Infringement and Enhanced Damages After Seagate: An Empirical Study 23 (working paper 2011) (finding that willfulness findings dropped only from $48.2 \%$ to $37.4 \%$ after Seagate, and that the change was not statistically significant).

$$
\text { 214. See, e.g,. Lichtman, supra note_, at n.42 ("very few }
$$

people read patents outside of the litigation and licensing contexts"); Roin, supra note _, at 2019-20 ("many innovators have ceased using patents as a research tool"). But see Ouellette, supra note _ (arguing that patents can be surprisingly useful sources of technical information, in part because online searching makes them more accessible). 
for twenty years. Even if the former case has been made, the latter has not.

The theory that patents are valuable for the information they disclose, then, doesn't seem to describe the real world-at least, not enough so to stand alone as a justification for having a patent system. ${ }^{215}$ But perhaps there is an alternative formulation of this theory, one in which the patent does not so much communicate valuable technical information itself as induce the communication of that information by other means.

One such indirect theory is that patents encourage public disclosure of information that would otherwise be kept secret. While the patents themselves don't create the useful disclosure, for the reasons just described, perhaps the existence of a patent induces inventors to elect patent over trade secret protection and, having done so, to publish their ideas in other forms beside just the patent. In fact, however, the available evidence suggests that companies primarily rely on patent protection to protect self-disclosing

\footnotetext{
215. Even a leading defender of current disclosure theory, Lisa Ouellette, does not go so far as to argue "that disclosure theory is a valid justification for the patent system." Ouellette, supra note __' at 1 . She makes no attempt to measure the social cost of patents or to compare the two, instead arguing only that if we already have a patent system, we are better off with one that requires disclosure because it may promote some learning. Id. at 20. That may be true, but as she acknowledges, it is not a free-standing justification for a patent system.
} 
inventions: those that the inventor could not maintain as a trade secret after putting it into commercial practice. If an invention can be kept secret, inventors are more likely to forego patent protection and keep it secret. ${ }^{216}$ While patent protection may induce some disclosure at the margins, trade secret law appears to do as much or more than patent law to encourage the disclosure of non-selfdisclosing inventions. ${ }^{217}$ And even if a party chose patent protection, it doesn't follow that it would decide to make the information available to competitors in other, more useful formats.

A second theory of indirect disclosure relies not on public disclosure of an invention but on the private communication of that invention. Arrow's Information Paradox suggests that parties may find it difficult to contract to disclose information in the absence of a

\footnotetext{
216. Two major cross-sectional surveys of inventors and R\&D managers find that they are much more likely to turn to the patent system to protect self-disclosing than non-self-disclosing inventions. See, e.g., Ashish Arora et al., R\&D and the Patent Premium, 26 Int'l
} J. Indus. Org. 1153 (2008); Wesley M. Cohen et al., R\&D Spillovers, Patents and the Incentives to Innovate in Japan and the United States,

31 Res. Pol'y 1349, 1350 (2002); Richard A. Levin et al., Appropriating the Returns From Industrial R\&D, 3 Brookings Papers on Econ. Activity 783 (1987). For a theoretical explanation of why this might be so, see Katherine J. Strandburg, what Does the Public Get: Experimental Use and the Patent Bargain, 2004 Wisc. L. Rev. 81.

217. Mark A. Lemley, The Suprising Virtues of Treating Trade Secrets as IP Rights, 61 stan. L. Rev. 311 (2008). 
property right over that information. ${ }^{218}$ Perhaps patents permit the licensing, not of the patents themselves, ${ }^{219}$ but of valuable information that would otherwise not have been disclosed among companies because of limitations in trade secret law. On this theory, the disclosure function of patents is not a public disclosure function

218. Kenneth J. Arrow, Economic Welfare and the Allocation of Resources for Invention, in Nat'l Bureau of Econ. Research, The Rate and Direction of Inventive Activity: Economic and Social Factors 609, 615 (1962) (arguing that sellers will not disclose information to buyers absent legal protection, and so buyers will be unable to value that information). There is substantial literature on patents as a way out of Arrow's paradox. See, e.g., James J. Anton \& Dennis A. Yao, Expropriation and Inventions: Appropriable Rents in the Absence of Property Rights, 84 Am. Econ. Rev. 190, 190-92 (1994); Paul J. Heald, Transaction Costs and Patent Reform, 23 Santa Clara Computer \& High Tech. L.J. 447, 453-54 (2007); Robert P. Merges, A Transactional View of Property Rights, 20 Berkeley Tech. L.J. 1477 (2005); Robert P. Merges, Intellectual Property and the Costs of Commercial Exchange: A Review Essay, 93 Mich. L. Rev. 1570, 1590 (1995). But see Burstein, supra note__ (arguing that we don't need patents to solve Arrow's Information Paradox, because structured disclosure of information and various other appropriability mechanisms can enable contracting).

219. Licensing of the patents themselves cannot alone justify a patent system, for there would be no need to license patents if patent rights didn't exist. 
at all, but a means of encouraging private technology transfer by creating rights that can in fact be transferred.

As a matter of theory, this licensing rationale for patent law makes considerable sense. But whether it is true is ultimately an empirical question. The confidentiality of licensing agreements makes it very difficult to answer that empirical question. But what evidence we have is not encouraging. We know that when patentees enforce patents in court, they virtually always do it not against people who learned from the patentee, but against independent developers. ${ }^{220}$ We don't know the percentage of patent licensing agreements that actually involve real technology transfer. Real know-how transactions often occur outside the scope of a patent license; it is the business people, not the lawyers, who get involved. By contrast, most corporate licensing programs seem to be an exchange of patent license rights for money, not an ongoing exchange of technological knowledge. Most license agreements I have seen don't have provisions for the ongoing disclosure of know-how, for instance. They are often cross-licenses, which tend not to involve technology transfer.

The evidence I review in this paper is somewhat mixed on the technology transfer point. The overwhelming predominance of independent invention suggests that most innovators are not in fact buying their knowledge from outsiders, but seeking to develop it on their own. On the other hand, some of the examples I give involve inventors who set out to find out what had already been done in the field, in at least a few cases by keeping up with other patents.

\footnotetext{
220. Cotropia \& Lemley, supra note _.
} 
Mostly, though, inventors sought their source of knowledge elsewhere; they seem to have followed patents to know what others owned, not to learn from them.

Further, as I have noted elsewhere, many features of the patent system are not well designed to facilitate technology transfer. ${ }^{221}$ The fact that patent applications are kept secret for at least 18 months, the absence of any defense for independent invention, the peripheral claiming system that encourages patentees to claim ground beyond what they in fact invented, the delays in the PTO, and the ability of applicants to change their claims using continuation applications throughout the twenty-year patent term all suggest that the focus of patentees and patent lawyers is not on actual technology transfer, but on maximizing the scope of legal rights.

That doesn't mean that patents play no role in technology transfer. The evidence from developing nations suggests that they dothat the developed world is more likely to share technology with countries that have at least some effective level of patent protection. ${ }^{22}$ And we can imagine changes to our patent law that would make it more effective in encouraging technology transfer in this country. ${ }^{223}$ But it means that licensing theory today can't be a full
221. Lemley, Ignoring Patents, supra note _.
222. L. Kamran Bilir, Patent Laws, Product Lifecycle Lengths, and the Global Sourcing Decisions of U.S. Multinationals (working

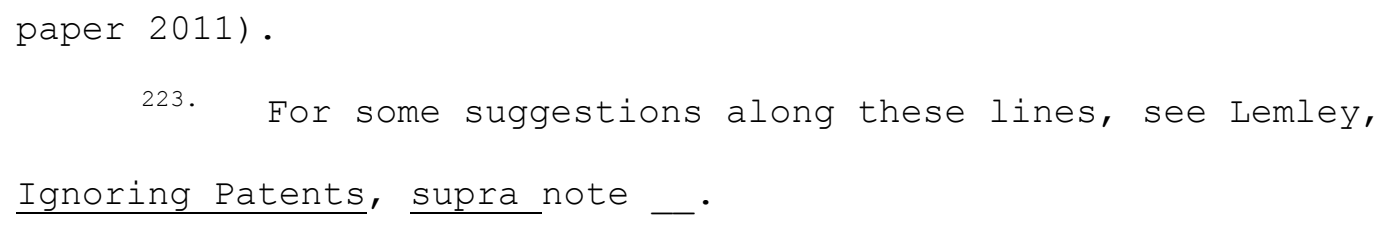


explanation for the pattern of licensing and enforcement behavior we observe.

\begin{abstract}
III. Patent Races: Toward an Alternative Theory of Patent Law
The three basic competing theories of patent law, then, don't seem to mesh with the realities of innovation. ${ }^{24}$ That's a problem. Does it mean that we should throw out patent law altogether, as
224. Other, non-economic theories of patent law are hard to take too seriously. For a discussion of reward-based theories of scientific invention stemming from natural law, see A. Samuel Oddi, Un-Unified Economic Theories of Patents-The Not-Quite-Holy Grail, 71 Notre Dame L. Rev. 267, 275-77 (1996); Kevin Rhodes, Comment, The Federal Circuit's Patent Nonobviousness Standards: Theoretical Perspectives on Recent Doctrinal Changes, 85 Nw. U. L. Rev. 1051, 1077-84 (1991); cf. Lawrence C. Becker, Deserving to Own Intellectual Property, 68 Chi.Kent L. Rev. 609, 609 (1993) (arguing that desert-based arguments for patent law are intuitively appealing, but do not necessarily justify the scope of current patent doctrine). Part of the reason is that patent law prohibits not just copying, but independent development. Indeed, the vast majority of patent lawsuits are filed against independent developers. See Christopher A. Cotropia \& Mark A. Lemley, Copying in Patent Law, 87 N.C. L. Rev. 1421 (2009). Jeanne Fromer has argued persuasively that inventors are often incented by rewards other than money, like prestige. Jeanne Fromer, Expressive Incentives in Intellectual Property (working paper 2011). But that is a justification for giving them those other sorts of rewards, not for giving them exclusive rights. 
Boldrin and Levine suggest? Perhaps. But before we jettison altogether what Mike Scherer has called "a system that, despite its manifest imperfections, has worked tolerably well,"225 we should consider whether we can find a theoretical justification for patent law that jibes with the historical evidence.

Such a justification would need to take account of the lessons of history:

- Invention is a social phenomenon, not one driven by lone geniuses. Inventors are working in groups, interacting with each other and building on the prior work of others. But even where they work independently, they are often working in parallel to solve identified problems or to improve existing technology.

- Central control doesn't seem desirable given the actual history of important inventions. Where we have given strong control to a single patent owner, the result has generally been reduced improvement and delayed commercialization.

- The first mover does not necessarily have the advantage in implementing pioneering inventions. While some of the examples I report above, such as the telephone, show a significant first-mover advantage, in other cases, like the airplane, the second mover ended up dominating the market. Where a first mover does prevail, it is generally the first to market with significant scale, not the first to invent, who reaps that advantage.

- A patent system that encourages innovation needs to encourage the diffusion of knowledge. Inventors are not working in isolation; they are affirmatively seeking out knowledge of what others are doing in

225. F.M. Scherer, Book Review of "Against Intellectual Monopoly,,$" 20$ Const. Pol. Econ. 94 (2009). 


\begin{abstract}
a field. The importance of cumulative innovation suggests that we need to make sure information is actually communicated between different workers building on related work.

In this Part, I offer some tentative thoughts about how to incorporate these ideas into out theories of the patent system, and a research agenda for future work.

While patents don't seem to be encouraging the development of discrete new ideas that no one else has, that doesn't mean they aren't motivating innovation at all. Rather, it means that the simple incentive-to-invent story must be complicated by the presence of competitors working to achieve the same invention at roughly the same time. Granting a patent to the first to achieve that goal doesn't just encourage one entrant; it may have a more complex set of incentives on different participants depending on how they perceive themselves relative to their competitors. The incentives provided by a patent, in other words, must be filtered through the realities of a patent race. In some (though by no means all, or even a majority) of the examples I discussed in Part I, the inventors were acutely aware of the possibility of patent rights and of the risk that others might obtain the core patents. The most notable example is the telephone. Alexander Graham Bell was aware not only of competitors working to develop a telephone, but of the filing of patent applications by those competitors. ${ }^{226}$ He rushed his application to the patent office before 226. This was possible because patents in the $1880 \mathrm{~s}$ issued quite quickly after filing. Edison's light bulb patent issued a mere three weeks after he filed it; other patents in the lighting field issued between two and seven months after filing. U.S. Patent No. 174,465
\end{abstract}


he finished his invention in order to avoid being preempted by others. Even then, he didn't beat his rivals to the patent office; Elisha Gray filed a caveat on the same day. ${ }^{227}$ Similarly, Eli Whitney was expressly warned that competitors were working on similar inventions and that he might lose patent rights if he didn't file quickly; that seems to have spurred him to file his patent application. ${ }^{228}$

Other examples involve not an explicit patent race, but plausibly evidence of a race to invent among different parties who were aware of each other's work and were racing to reach a goal before their competitors. Edison was aware of the work of others on the light bulb, and it is plausible that his knowledge of that other work not

(Mar. 7, 1876) (filed Feb. 14, 1876). In addition, at the time inventors could file what was known as a "caveat," indicating that they were working in an area and asking to be notified if anyone else filed a patent application in that field. Patent Act of 1836, \$ 12 . Caveats were discontinued in 1909.

By contrast, by the late 1990 s the pendency rate was an average of 2.77 years, John R. Allison \& Mark A. Lemley, Who's Patenting What? An Empirical Exploration of Patent Prosecution, 53

Vand. L. Rev. 2099 (2000), and it has gone up substantially since then. While most applications are published after 18 months, even an inventor who was reading those applications would find it difficult today to know what competitors were doing in anything like real time. 227. http://0.tqn.com/d/inventors/1/7/r/X/graypatent.gif

(reproducing Gray's caveat of Feb. 14, 1876).

228. Lakwete, supra note _-' at 58-61. 
only shaped his invention but caused him to move more quickly. Similarly, the Wright Brothers recognized that they were in competition with other inventive teams to be the first to achieve powered flight. Watson and Crick knew they were racing Linus Pauling to discover the helical structure of DNA, and winning the race was a powerful motivator for them. ${ }^{229}$

Finally, even among the majority of cases in which we have no evidence of an explicit race, that doesn't mean there was no race. Many of the examples show explicit awareness by the inventor of prior work in the field. Morse, for instance, kept up with what others were doing in the field. Jenkins built on Edison's kinetoscope. And so on. ${ }^{230}$ It is possible that these inventors knew they were racing against identifiable others working on the same thing. And even if they didn't know, they may well have been spurred to quick action by the fear that unknown others were out there doing the same thing. Standard economic theory holds that racing, whether to develop a new invention or to get that invention to market, is a wasteful exercise. ${ }^{231}$ After all, the point of patent law is to encourage

229 http://www.exploratorium.edu/origins/coldspring/ideas/printit.htm 1 .
230.
For other examples, see Vermont, supra note _, at 478-79.
231.
For the standard economic analysis of patent races, see

Jean Tirole, The Theory of Industrial Organization 394-414 (1988);

Partha Dasgupta \& Joseph Stiglitz, Uncertainty, Industrial Structure, and the Speed of R\&D, 11 Bell J. Econ. 1 (1980); Yoram Barzel, The Optimal Timing of Innovations, 50 Rev. Econ. \& Stat. 348,352 n.11 
(1968); Donald G. McFetridge \& Douglas A. Smith, Patents, Prospects and Economic Surplus: A Comment, 23 J.L. \& Econ. 197, 198 (1980). For criticism of patent races, see Pankaj Tandon, Rivalry and the Excessive Allocation of Resources to Research, 14 BELL J. ECON. 152 (1983) (lamenting the excessive duplication of research); Partha Dasgupta \& Paul Stoneman, The Economic Theory of Technology Policy: An Introduction, in Economic Policy and Technological Performance 18-21 (Partha Dasgupta \& Paul Stoneman eds., 1987) ("[T]he winner-takes-all form of compensation to research units... encourages excessive R\&D investment and excessive risk-taking on the part of R\&D units competing for the prize."); Jennifer F. Reinganum, The Timing of Innovation: Research, Development, and Diffusion, in 1 Handbook of Industrial Organization 849 (Richard Schmalensee \& Robert D. Willig eds., 1989) (discussing the costs of patent races); Mark F. Grady \& Jay I. Alexander, Patent Law and Rent Dissipation, 78 Va. L. Rev. 305, 306 (1992) (same); Matthew Erramouspe, Comment, Staking Patent Claims on the Human Blueprint: Rewards and Rent-Dissipating Races, 43 UCLA L. Rev. 961, 962 (1996) ("Although a gold rush has its winners, many claims are ultimately unproductive, and thus many prospectors waste valuable resources and go unrewarded. Gold rushes are also unproductive in a broader social sense. Follow-on prospectors bid resources away from higher valued uses outside the prospecting industry to lower valued uses inside it."); Suzanne Scotchmer, Incentives to Innovate, in The New Palgrave Dictionary of Economics and the Law 273, 275 (Peter Newman ed., 1998) ("The literature has produced two views of patent races: that they inefficiently duplicate 
investments in research and development that wouldn't otherwise be made. If two or more putative inventors invest that money in R\&D in an effort to beat each other to the market, all but the first to invent will have wasted that money. ${ }^{232}$ Further, they may deliberately overspend in hopes of getting the prize of a patent, dissipating the social value of the new invention. ${ }^{233}$ As a result, prospect theory

costs, and that they efficiently encourage higher aggregate investment."). cf. Doug Lichtman et al., Strategic Disclosure in the Patent System, 53 Vand. L. Rev. 2175, 2177 (2000) (discussing the strategic disclosure of information by participants in patent races); Gideon Parchomovsky, Publish or Perish, 98 Mich. L. Rev. 926, 929-30 (2000) (same). Michael Abramowicz discusses the literature in a Michael Abramowicz, The Uneasy Case for Patent Races Over Auctions, 60 Stan. L. Rev. 803 (2007). 232. Louis Kaplow, The Patent-Antitrust Intersection: A Reappraisal, 97 Harv. L. Rev. 1813, 1869 (1984) (making this wastedinvestment argument). Indeed, Yoram Barzel analogizes patent races to the tragedy of the commons because they involve "overuse" of research. Yoram Barzel, Optimal Timing of Innovations, 50 Rev. Econ. \& Stat. 348 (1968) .

233. Mark A. Grady \& Jay I. Alexander, Patent Law and Rent Dissipation, 78 Va. L. Rev. 305, 313-16 (1992); William M. Landes \& Richard A. Posner, The Economic Structure of Intellectual Property Law 16-17 (2003); Vermont, supra note_, at 491-92. Suzanne Scotchmer claims that "the firms in the patent race make zero profit in expectation" because it has all been dissipated by wasteful efforts to 
justifies the central control it would provide over innovations in substantial part as a way of avoiding wasteful patent races. ${ }^{234}$ And even opponents of that theory are careful to argue that encouraging later filing in patent cases won't encourage patent races. ${ }^{235}$ In fact, though, patent races can have substantial benefits. First, as John Duffy has observed, the benefit of a race is that people run faster than they otherwise would. ${ }^{236}$ As a result, a patent race should both cause inventions to be made sooner than they otherwise would be and, because patent terms are measured from the filing date, cause the resulting patents to expire earlier than they otherwise would. The parties to the race may or may not dissipate their private rents, but society benefits both from the earlier invention and from the earlier entry of the invention into the public domain. And because inventions tend to be cumulative, the earlier

win the race. Suzanne Scotchmer, Ideas and Innovations: Which should be subsidized?, NBER Working Paper at 2 (Jan. 11, 2011), available at http: //ssrn.com.abstract $=1755091$.

234. Kitch, supra note _, at _.

235. See, e.g., Christopher A. Cotropia, The Folly of Early

Filing in Patent Law, 61 Hastings L.J. 65 (2009).

236. John F. Duffy, Rethinking the Prospect Theory of Patents,

71 U. Chi. L. Rev. 439, 476-80 (2004). Duffy refers to his theory as a branch of prospect theory, but in fact it is not only distinct from but decidedly at odds with prospect theory's hostility to patent races. 
invention date also means that we should get a cascade of improvements earlier than we otherwise would.

Second, the idea that races involve a wasteful duplication depends on the assumption that the parties achieve the same end in the same way. But very often that is not true. Inventors racing to solve a problem quite often solve the problem in different ways. ${ }^{237}$ And when they do, they contribute something valuable to the world that we would not have obtained from a single inventor taking one approach. ${ }^{238}$ If the

237. Giovanni De Fraja, Strategic Spillovers in Patent Races, 11 Int'l J. Indus. Org. 139, 140 (1993); Jennifer F. Reinganum, A Dynamic Game of $\mathrm{R}$ and $\mathrm{D}$ : Patent Protection and Competitive Behavior, 50

Econometrica 671, 671 (1982).

238. Robert P. Merges, Rent Control in the Patent District: Observations on the Grady-Alexander Thesis, 78 Va. L. Rev. 359, 381 (1992). Courts and commentators have recognized the value of different approaches in another, related context: efforts to design around an existing patent. Warner-Jenkinson Co., Inc. V. Hilton Davis Chem. Co., 520 U.S. 17, 36 (1997) (contrasting "the intentional copyist making minor changes to lower the risk of legal action" with "the incremental innovator designing around the claims, yet seeking to capture as much as is permissible of the patented advance."); see also Slimfold Mfg. Co. v. Kinkead Indus. Inc., 932 F.2d 1453, 1457 (Fed. Cir. 1991) (Rich, J.) ("Designing around patents is, in fact, one of the ways in which the patent system works to the advantage of the public in promoting progress in the useful arts, its constitutional purpose."); State Indus. v. A.O. Smith Corp., 751 F.2d 1226, 1236 (Fed. Cir. 1985) 
problem is powered human flight, for example, both airplanes and helicopters are desirable solutions to that problem, even thoughindeed, because-they differ in various respects. The mere existence of two alternatives provides valuable competition, even if the two are equally good. Further, different approaches will quite often be better in some circumstances than others. Some patients respond better to some drugs than others, even if overall the drugs have an equivalent therapeutic effect. Some customers prefer one type of cereal to a nutritionally equivalent alternative. And different inventions can be platforms for different types of subsequent improvement. Indeed, some quite valuable inventions have come from unexpected new applications of existing technology, including the Post-It note and the cardiac pacemaker. Aylsworth discovered chemical vapor deposition in the course of trying to design a light bulb with a non-carbon filament in an effort to avoid Edison's patents. The fewer different implementations of an invention we have, the less likely it is we will encounter those serendipitous reuses or entirely new directions. The

("One of the benefits of a patent system is its so-called 'negative incentive' to 'design around' a competitor's products, even when they are patented, thus bringing a steady flow of innovations to the marketplace."); Craig Allen Nard, A Theory of Claim Interpretation, 14 Harv. J. L. \& Tech. 1 (2000) ("The practice of designing around extant patents creates viable substitutes and advances, resulting in competition among patented technologies. The public clearly benefits from such activity."); Matthew J. Conigliaro et al., Foreseeability in Patent Law, 16 Berkeley Tech. L.J. 1045 (2001). 
Post-It note worked because 3M had developed a specific type of glue, despite the fact that it already had plenty of other glues; if we didn't have a number of different types of glue, we probably wouldn't have the Post-It note.

Finally, inventors may work better when they are under some deadline pressure. The proverb is "necessity is the mother of invention." While prospect theory posits that monopolists will have the right economic incentives to improve on their products, for the reasons noted above, it is often competition, not monopoly, that spurs innovators to action. ${ }^{239}$ So it may not only be that we get innovation

\footnotetext{
239. Kenneth J. Arrow, Economic Welfare and the Allocation of Resources for Invention, in THE RATE AND DIRECTION OF INVENTIVE ACTIVITy 609, 620 (Nat'l Bureau of Econ. Research ed., 1962), reprinted in 5 KENNETH J. ARROW, COLLECTED PAPERS OF KENNETH J . ARROW: PRODUCTION AND CAPITAL 104, 115 (1985); F.M. Scherer \& David Ross, Industrial Market Structure and Economic Performance 660 (3d ed. 1990) (criticizing Schumpeter's "less cautious" followers for advocating monopoly to promote innovation); Morton I. Kamien \& Nancy L. Schwartz, Market Structure and Innovation (1982); Shelanski, supra note__, at 85 (finding that competition was a greater spur to innovation than monopoly in ten empirical studies in the telecommunications industry); Mark A. Lemley \& Lawrence Lessig, The End of End-to-End: Preserving the Architecture of the Internet in the Broadband Era, 48 UCLA L. Rev. 925, 960-62 (2001) (arguing that the Internet was as innovative as it was because its architecture required competition rather than monopoly bottlenecks); Aamir Rafique Hashmi,
} 
more quickly as a result of competitive pressure, but that we get better quality ideas as a result. It's hard to know how significant a role this plays; the more logical inference from independent invention is that we would have gotten the new idea anyway. ${ }^{240}$ But it is at least possible that but for the spur of competition, none of the racing parties would ever have gotten to the invention. ${ }^{241}$

Patent races, then, may have gotten a bad rap. It is possible that patents encourage putative inventors to race to achieve a result

Competition and Innovation: The Inverted-U Relationship Revisited (working paper Feb. 15, 2011) (finding strong evidence of a positive relationship between competition and innovation). Indeed, a review of the economic literature indicates that competition even makes monopolists more efficient. See Thomas J. Holmes \& James A. Schmitz, Jr., Competition and Productivity: A Review of Evidence, 2010 Ann.

Rev. Econ. 619, 620-21.

240. Vermont, supra note_, at 478 (suggesting that valuable inventions that are independently developed likely would have been developed even without a patent incentive).

241. Studies of actual physical races suggest that participants go faster and last longer when they are in the presence of another competitor, even if they are not explicitly trying to beat that competitor. http://running.competitor.com/2011/04/training/why-youshouldn $\div 2 \div 80 \% 99 t-\% \mathrm{E} 2 \% 80 \div 9$ Crun-your-own-race $\% 2 \% 80 \% 9 \mathrm{D} 24463$. So there may be psychological and even physiological reasons why we are hardwired to perform better when competing against others. 
first, and that doing so gets us a greater variety of inventions more quickly than we would have in the absence of patent protection. As a descriptive matter, the evidence suggests that for better or worse the patent system is about patent racing. And I have suggested that racing can have substantial benefits. But for the encouragement of patent races to serve as a justification for the patent system, more is required. First, we would want evidence that it is the race for a patent, not just the race for recognition or to be first, that motivates inventors. As we have seen, at least some of the inventions (the cotton gin and the telephone) were explicitly patent races. But other races might have occurred even without a patent system, because there are substantial reputational advantages to being first. Indeed, one might say that our society is obsessed with races, valorizing the winners of Olympic events whose times are virtually indistinguishable from the second-place finisher, and awarding prizes and name recognition to a few scientists while disregarding the work of others. We might not need the patent to provoke a race; society itself may provide plenty of incentive. Next, assuming that it is the patent that is motivating the race, it is worth distinguishing between two different aspects of the race that might motivate participants: the carrot and the stick. The traditional view of the patent system is as a carrot, a reward dangled in front of the inventor to lure investment in research. Patent racing changes the nature of the carrot - the promise is not of a patent as reward for successful invention, but of some chance of a carrot (if the inventor wins the race) and some chance of nothing (if she doesn't). That complicates the calculus of patent incentives, as 
discussed further below, but it doesn't overthrow the basic story altogether.

Patents in a race can also serve as a stick, however. This approach adopts and inverts Arrow's competitive innovation paradigm. Inventors aren't driven by the lure of being a monopolist so much as by the risk of losing a race and being excluded from competition in that market. Even inventors who don't care much about winning the patent and excluding competitors may care very much about being excluded from the market by others; at a minimum, they want freedom to operate. The patent isn't a carrot so much as a stick with which to threaten the slow. Patents themselves might well be undesirable on this theory; we keep them because the race to get them and therefore not be excluded has positive effects that outweigh the inefficiencies resulting from the distortion they impose on markets.

Whether we think patent racing is predominantly about carrots or about sticks matters, because they have rather different implications for the structure of the patent system. A patent-racing patent system is very much concerned with ex ante incentives. Whether a patent gives control over downstream improvements matters only if the racing parties think it matters. If they are racing in the hope of achieving enduring patents that will provide the broad ability to exclude others from the market, that is what patent law should provide. By contrast, if racing parties have some other expectation-if what they are racing for is a patent that they think will give them some sort of financial security, or a patent that allows them the freedom to operate, rather 
than the right to exclude, then that is all patent law need provide. ${ }^{242}$ That concern with incentives may mean that patent law should operate like a lottery, offering not the promise of a small reward but a small chance of a large payoff. Patentees, like purchasers of a lottery ticket, appear to over-value the small chance of a large reward, so we may get more innovation from such a system. ${ }^{243}$

But inventors may also be racing to complete the invention in order to avoid losing out in a patent race. Here, the "incentive" offered by the patent system is not the promise of a payoff, but the threat of being taxed or even excluded from the market entirely if they lose the race. This stick-as opposed to the normal carrot of the incentive-to-invent story-represents a significant difference between the two theories. An incentive-to-invent theory focuses on only one party-the putative extraordinary inventor who does something others cannot. Once we introduce multiple inventors, the effect of the patent system on invention becomes some combination of the positive and negative incentives. And while on the positive side a racer might want strong control over downstream improvements, or a probabilistic chance at a huge payoff, a racer concerned with losing the race would want the opposite.
242.
Fromer, Expressive Incentives, supra note _.
243. F.M. Scherer, The Innovation Lottery, in Expanding the

Boundaries of Intellectual Property 3, 3 (Rochelle C. Dreyfus et al. eds., 2001); Dennis D. Crouch, The Patent Lottery: Exploiting Behavioral Economics for the Common Good, 16 Geo. Mason L. Rev. 141, $143-45$ (2008) 
Until 2011, the reward for winning a patent race was absolute: the first to invent gets a patent, and the loser gets nothing, not even the right to continue using the product they themselves developed. ${ }^{244}$ This is not a small feature of the patent system; Chris Cotropia and I have demonstrated that the overwhelming majority of patent lawsuits are filed not against people who copy the invention from the patentee, but against independent inventors. ${ }^{245}$ On an incentive-to-invent theory, that's a problem, because it suggests that the law is primarily enforcing patent rights in cases in which there are multiple independent inventors of the same thing. ${ }^{246}$ But if we are encouraging racing, that's not necessarily a problem. It may even be a

\footnotetext{
244 Wolfgang Leininger describes the patent system as an "all pay" auction in which both winners and losers must pay, but only the highest bidder wins. Wolfgang Leininger, Escalation and Cooperation in Conflict Situations, 33 J. Conflict Resol. 231, 233 (1989).

In September 2011, Congress passed the Leahy-Smith America Invents Act. That Act moved the United States from a first-to-invent to a modified first-to-file system, effective with patent applications filed late in 2012. It also created a prior user right that applies to process inventions. H.R. 1249 (2011).

245. Cotropia \& Lemley, supra note _. 246 For arguments for various forms of market sharing with simultaneous inventors, see, e.g, Vermont, supra note _ ; Stephen M. Maurer \& Suzanne Scotchmer, The Independent Invention Defense in Intellectual Property, 69 Economica 535 (2002); Carl Shapiro, Prior User Rights, 96 Am. Econ. Rev. Papers \& Procs. 92 (2006).
} 
virtue. Granting prior user rights or avoiding injunctions would somewhat reduce the incentive given to the winner, but it would also reward those who were a close second in the race. That would reduce the "stick" incentive to race, since the loser would not have as much to lose. ${ }^{247}$ The effects on the carrot side would be more complex, since they will depend on whether the individual racers think they are likely to win and on whether they are risk-averse or risk-preferring (that is, whether they would prefer a chance at a large payoff to a certainty of a small payoff). Under plausible assumptions, inventors are both risk-takers and overly optimistic. ${ }^{248}$ If so, the winner-takeall feature is likely to drive entrants to run the race, both because they think they are likely to win and because they are willing to take the risk of losing. ${ }^{249}$

Notably, a patent racing theory does not depend on the nonobviousness of the invention or the inability of others in the field to achieve it. Rather, the argument is that the possibility of obtaining a patent before someone else spurs inventors to act in ways

\footnotetext{
247 Economists refer to this as the "competitive threat." J. Beath et al, Strategic R\&D Policy, 97 Econ. J. 32 (1989); Vincenzo Denicolo \& Luigi Alberto Franzioni, on the winner-take-all principle in innovation races, 8 J. Eur. Econ. Ass'n 1133 (2010) ("One virtue of the winner-take-all system is that it maximizes the competitive threat by making the consolation prize vanish.") .

248 See Scherer, supra note _, at __' Crouch, supra note _, at 249 Accord Denicolo \& Franzioni, supra note _.
} 
they otherwise would not, producing quicker or better or different inventions. Indeed, Ben Roin has suggested that companies in the pharmaceutical industry may be extremely concerned with the outcome of races, to such an extent that they will not develop even new chemical products with substantial market demand unless they can be sure that they will get the rights to the chemical. ${ }^{250}$ Pharmaceutical companies may, then, be exhibiting an extreme form of racing behavior, calling off searches if they think they will end up in second place. Depending on whether one believes the carrot or the stick predominates, a patent system designed to encourage patent races might look rather different than the one we have today. We would pay lessperhaps even no-attention to the knowledge of others of skill in the art. Simultaneous invention would not necessarily be evidence against the granting of a patent, as it sometimes is today. ${ }^{251}$ Indeed, on a patent racing theory we might be more likely to grant patents in precisely those circumstances in which we expect others to be working on the same problem. A patent racing theory might well support the recent switch from a first-to-invent to a first-to-file system, as parties concerned with entering a patent race should have some way to

250. Benjamin N. Roin, Unpatentable Drugs and the Standards of Patentability, 87 Tex. L. Rev. 503 (2009). 251. See, e.g., Hybritech, Inc. v. Monoclonal Antibodies, Inc., 802 F.2d 1367, 1380 n.4 (Fed. Cir. 1986). For discussion of the role of simultaneous invention in obviousness, see Mark A. Lemley, Should Patent Infringement Require Proof of Copying?, 105 Mich. L. Rev. 1525 (2007) . 
find out whether they have won. But it might be more skeptical of prior user rights, especially if they have the effect of substantially diluting the benefits patentees get by winning a race.

Finally, a patent racing theory, like any other, must contend with the effects on third parties. Granting strong patent rights isn't costless; it raises the cost of the products once sold, it may delay commercialization of the invention, and it may raise the cost of later improvements. ${ }^{252}$ And encouraging patent races may have specific social costs. For instance, it may encourage secrecy rather than openness in the period leading up to the invention, as racers seek an edge over their rivals. And our historical examples suggest that the exchange of information was integral to innovation in many cases. So to know whether patent racing theory justifies patent protection, we need to do the same sort of balancing as in incentive-to-invent theory. We want to know, in short, whether the innovation benefits of granting patent rights exceed their costs.

The risk of losing a patent race represents an ironic justification for exclusivity. We are using the implicit threat of keeping the inventor's product out of the market as an incentive to hurry an inventor along in inventing and then in filing a patent, and the prospect of a monopoly as a spur to competition. Given the substantial differences between patent racing theory and existing law, we need better evidence than we have today about how important racing incentives are in driving innovation across a range of industries and

252. Lemley, Economics of Improvement, supra note _. 
at what cost before we can conclude that racing theory justifies patent law.

Whether and to what extent racing motivates inventors in the real world - and whether it is the carrot or the stick that motivates them - is unclear, and calls out for further research. We might seek evidence to support, refute, or refine patent racing theory from a variety of sources.

- First, we might survey inventors about what motivates their behavior. There are some such surveys already, most notably the Berkeley Entrepreneurship Survey, but they have not been focused specifically on patent racing. ${ }^{253}$ The literature on optimism bias among inventors ${ }^{254}$ seems relevant here, because it would push against a "risk of losing" racing theory. The literature on intrinsic motivation is also relevant; if people are inventing for the joy of it, and not particularly worried about market position, patents are more a cost than a benefit. ${ }^{255}$ And because most invention today is corporate, not individual, we need to think about the motivations of companies, who may be more likely to be racing for market position than for patent exclusivity.

253. Stuart J.H. Graham et al., High Technology Entrepreneurs and the Patent System: Results of the 2008 Berkeley Patent Survey,

24 Berkeley Tech. L.J. 1255 (2009).

254. See, e.g., Crouch, supra note _ ; Scherer, supra note _. 255 For a survey of that literature, see, e.g., Fromer, supra note _; Diane Leenheer Zimmerman, Copyrights as Incentives: Did We Just Imagine That?, 12 Theoretical Inq. L. 29, 42-54 (2011). 
- Second, we might pay more attention to the behavior and motivation of participants in interference proceedings and priority contests, who we know ended up in a patent race, intentionally or not.

- Third, we should pay careful attention to industry-specific differences in racing motivations. We know those differences exist for every other patent theory, ${ }^{256}$ and it seems likely that will be true of patent races as well.

- Fourth, we need to think carefully about how a theory of racing intersects with the reality of invention not as a discrete activity, but as a continuous series of improvements. Even if parties are racing to one milepost, the race to produce a particular invention is not the end of the story. For most technologies, if there is a patent race, it is a relay race; where any participant starts may depend on where others have ended. Whether racing theory can justify the patent system depends in significant part on how racing incentives at one stage create rights that may affect innovation (and racers) at later stages. That is even more true today, when inventors seem to file multiple patent applications on small parts of a large, multi-component product. It is one thing to view oneself as in a race to build and patent a working telegraph; it is quite another to think of "racing" to invent a particular circuit layout that is one small piece of a vast effort to produce a new microprocessor.

- Fifth, we should think about how the patent system impacts the small but significant category of accidental inventions. Patent law today does not care how an invention is made; it protects accidental as

256. See Dan L. Burk \& Mark A. Lemley, The Patent Crisis and How the Courts Can Solve It ch. 6 (2009). 
well as deliberate inventions. ${ }^{257}$ But a racing model is explicitly about deliberate rather than accidental invention; it may not justify patent protection for those who invented without intending to do so.

- Finally, we need to think about how patents play into the motivations of all participants, not just those who end up seeking a patent. We know that in many industries people invent for a variety of reasons that have little to do with the prospect of financial reward. ${ }^{258}$ And some literature also points to the prevalence of strategic disclosure of information outside the patent system by participants in invention races. ${ }^{259}$ Races may be won by inventors with no interest in patenting; that fact will affect racing incentives. Those non-patenting inventors will benefit from prior user rights, and that fact might be enough to justify the creation of those rights even under a racing theory.

There is much to think about here. Patent racing is not-yet-a developed theory of patent incentives. But as we assess the most important inventions of the last two centuries, it is certainly a phenomenon that deserves further elaboration. For it is more descriptive of the way the world actually works than any of the theories we have today. Given the historical evidence, if you are skeptical of the benefits of patent racing, you probably ought to be skeptical of the benefits of the patent system as a whole.

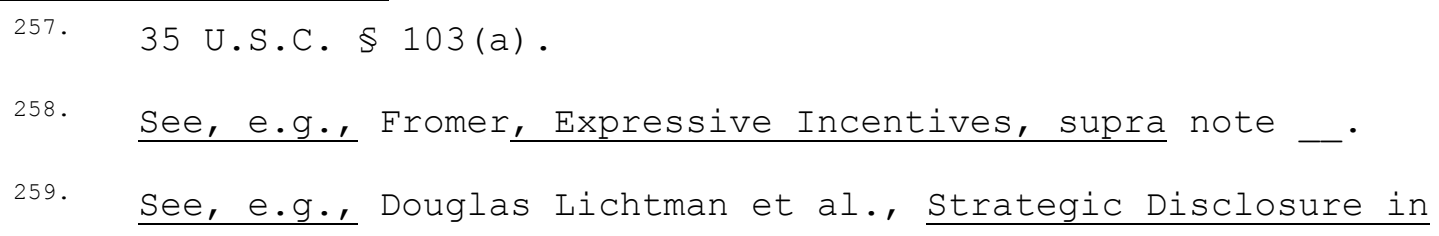




\begin{abstract}
Conclusion
The history of significant innovation in this country is, contrary to popular myth, a history of incremental improvements generally made by a number of different inventors at roughly the same time. Our patent system, by contrast, is designed for a world in which one inventor of extraordinary skill does something no one else could have done. The resulting disconnect is a problem not only for patent theory but for the design of the patent system, which seems to be based on assumptions about invention that are not borne out by reality

If we are to justify the patent system, we need an alternative theory. Commercialization and disclosure stories-the two alternatives to the incentive to invent theory most commonly articulated-don't seem to fit the bill.

The solution may come from a surprising source-a theory of patent racing that is focused not merely on the positive incentives from inventing something new, but from the fear of being beaten by the competition. Racing theory may or may not be the answer we are looking for; there is some reason to think that there is no one unified theory that explains all of patent law. ${ }^{260}$ But at a minimum, it is a partial explanation for how patents might fit into the innovation puzzle, one based on evidence about how patents seem to work in the real world. And even a partial explanation is better than what we have right now.
\end{abstract}

260. Burk \& Lemley, supra note _. 


\begin{abstract}
About this Table of Contents:
Word generates the following table of contents using the heading styles. You can update it by right-clicking on it and selecting "Update Field." You will have the option of updating just the page numbers (which also automatically update when you print) or the entire table, which will re-create the table of contents. If you have added headings, it is important that the correct heading style be applied; this table of contents is a good way to double-check that.

You can jump to any heading in the document by control-clicking on the page number.
\end{abstract}

